4.

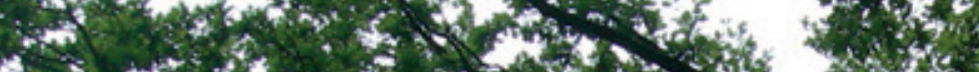

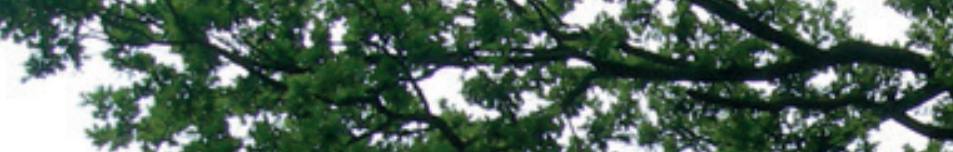

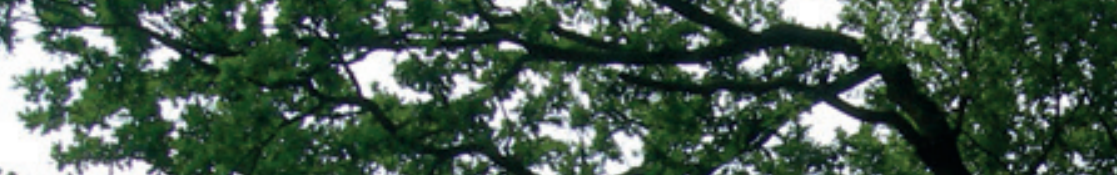

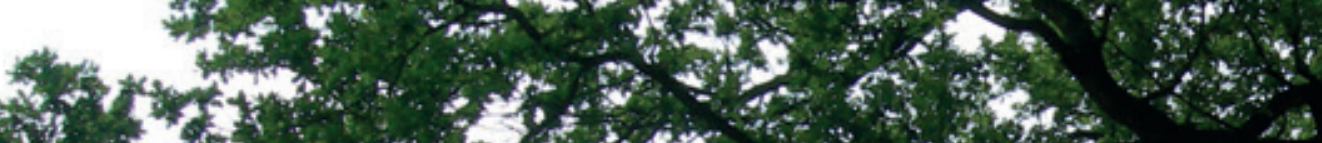

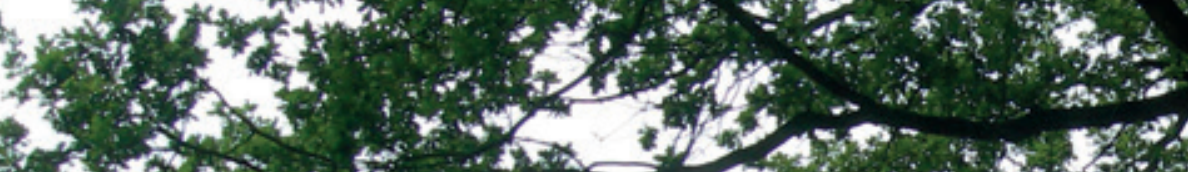

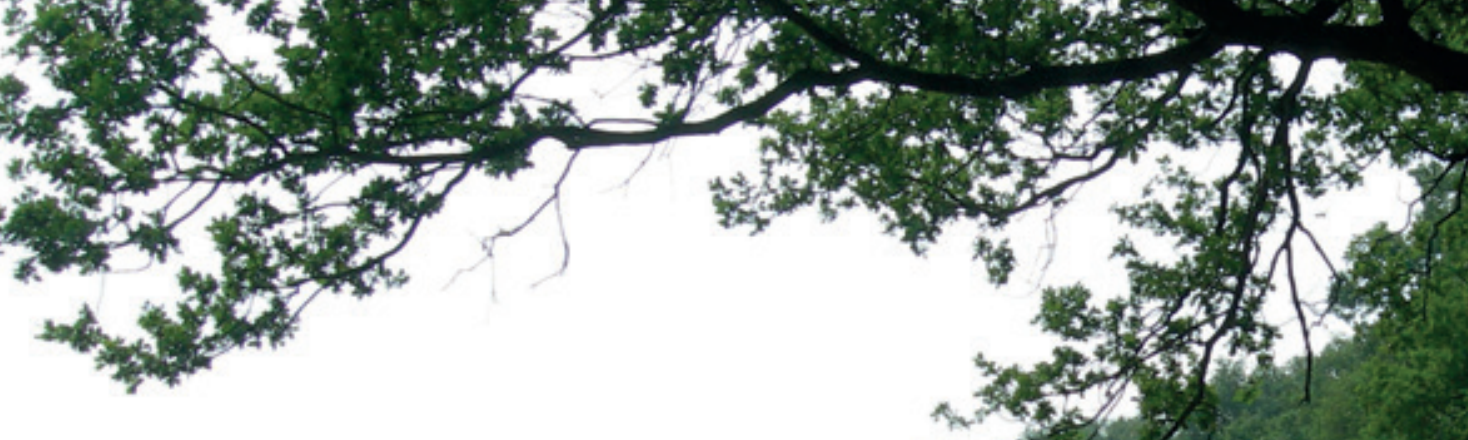
ato
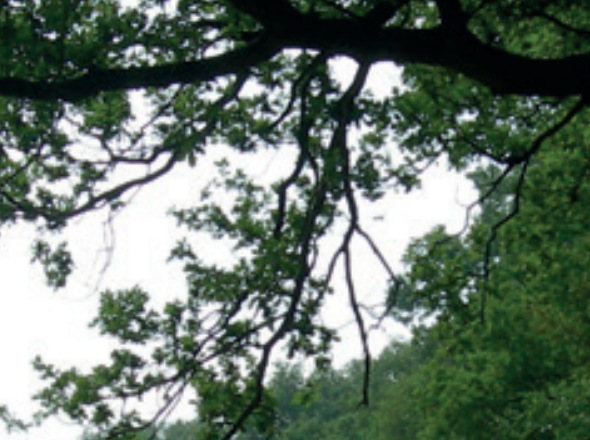

\title{
Marktverkenning biomassareststromen
} hout uit landschap 



\section{Marktverkenning biomassareststromen hout uit landschap}

Joop Spijker ${ }^{1}$, Wolter Elbersen², Iris Vural Gursel ${ }^{2}$, Bas Lerink ${ }^{1}$

1 Wageningen Environmental Research

2 Wageningen Food \& Biobased Research

Dit onderzoek is uitgevoerd door Wageningen Environmental Research in opdracht van en gefinancierd door Rijkswaterstaat Infrastructuur \& Milieu.

Wageningen Environmental Research

Wageningen, maart 2020

Gereviewd door:

prof. dr. ir. GJMM Nabuurs, Hoogleraar Europees Bos

Akkoord voor publicatie:

dr. ir. NAC Smits, teamleider van Vegetatie, Bos- en Landschapsecologie

Rapport 2991

ISSN 1566-7197 
Spijker JH, HW Elbersen, I Vural Gursel en BJW Lerink, 2020. Marktverkenning biomassareststromen hout uit landschap. Wageningen, Wageningen Environmental Research, Rapport 2991. 42 blz.; 8 fig.; 6 tab.; 23 ref.

Hout uit het landschap wordt nu vooral voor energieproductie (elektriciteit en warmte) ingezet. Het is niet eenvoudig dit hout hoogwaardiger in te zetten onder meer door de relatief lage kwaliteit, de geringe uniformiteit en de geringe volumes. Dit rapport schetst een beeld van de huidige afzet van houtige biomassa uit landschap. Voorts wordt een classificatie geschetst van houttoepassingen naar functionaliteit en wordt ingegaan op de toepassing van hout als zaaghout, vezeltoepassingen, monomere toepassingen en energie-toepassingen. Tenslotte schetst het rapport een handelingsperspectief voor producenten, verwerkers en afnemers van hout uit landschap en betrokken overheden om te komen tot duurzamere toepassingen van dit hout.

Woody biomass from landscape elements is currently primarily used for energy generation (heat and electricity). Developing high-value applications for this type of biomass is complicated, due to its relatively low quality, the lack of uniformity and the small volumes. This report identifies and quantifies current flows of woody biomass from landscape elements. Furthermore, the different applications for woody biomass are classified based on their functionality. The report also further examines the application of biomass for the production of lumber, pulpwood, monomers and for energy generation. Lastly, the report describes a framework for action, targeting producers, processors and buyers of woody biomass from landscape elements and involved governments, to further develop high-value applications of biomass.

Dit rapport is gratis te downloaden van https://doi.org/10.18174/520258 of op www.wur.nl/environmental-research (ga naar 'Wageningen Environmental Research' in de grijze balk onderaan). Wageningen Environmental Research verstrekt geen gedrukte exemplaren van rapporten.

2020 Wageningen Environmental Research (instituut binnen de rechtspersoon Stichting Wageningen Research), Postbus 47, 6700 AA Wageningen, T 0317480700 , www.wur.nl/environmental-research. Wageningen Environmental Research is onderdeel van Wageningen University \& Research.

- Overname, verveelvoudiging of openbaarmaking van deze uitgave is toegestaan mits met duidelijke bronvermelding.

- Overname, verveelvoudiging of openbaarmaking is niet toegestaan voor commerciële doeleinden en/of geldelijk gewin.

- Overname, verveelvoudiging of openbaarmaking is niet toegestaan voor die gedeelten van deze uitgave waarvan duidelijk is dat de auteursrechten liggen bij derden en/of zijn voorbehouden.

Wageningen Environmental Research aanvaardt geen aansprakelijkheid voor eventuele schade voortvloeiend uit het gebruik van de resultaten van dit onderzoek of de toepassing van de adviezen.

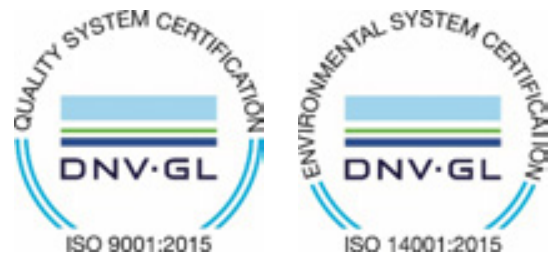

Wageningen Environmental Research werkt sinds 2003 met een ISO 9001 gecertificeerd kwaliteitsmanagementsysteem.

In 2006 heeft Wageningen Environmental Research een milieuzorgsysteem geïmplementeerd, gecertificeerd volgens de norm ISO 14001.

Wageningen Environmental Research geeft via ISO 26000 invulling aan haar maatschappelijke verantwoordelijkheid.

Wageningen Environmental Research Rapport 2991 | ISSN 1566-7197

Foto omslag: Wageningen UR 


\section{Inhoud}

$\begin{array}{ll}\text { Verantwoording } & 5\end{array}$

$\begin{array}{ll}\text { Samenvatting } & 7\end{array}$

$\begin{array}{ll}\text { Summary } & 9\end{array}$

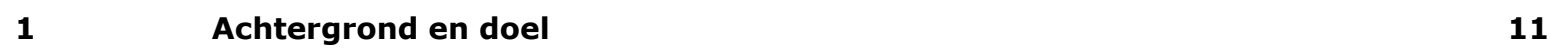

1.1 Achtergrond 11

1.2 Doel 11

$\begin{array}{ll}1.3 \text { Methode } & 11\end{array}$

1.4 Karakterisering houtige biomassa uit landschap $\quad 12$

$\begin{array}{lll}1.5 & \text { Projectafbakening } & 13\end{array}$

$2 \quad$ Huidige afzet houtige biomassa uit landschap $\quad 14$

2.1 Schatting huidige afzet $\quad 14$

2.1.1 Reflectie schatting huidige afzet $\quad 16$

2.1.2 Regionale beschikbaarheid 17

$\begin{array}{ll}2.1 .3 \text { Ketens } & 18\end{array}$

2.2 Potentiële productie van hout en houtige biomassa uit het landschap 19

2.2.1 Huidige stand van zaken 19

2.2.2 Vooruitblik naar 2030 en $2050 \quad 20$

2.3 Reflectie op huidige prikkels voor de inzet van houtige biomassa uit landschap 22

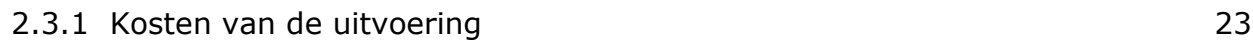

2.3.2 Eigen gebruik $\quad 23$

$\begin{array}{ll}2.3 .3 \text { Subsidie } & 23\end{array}$

2.3.4 Sociaal-cultureel, samenwerking 23

2.3.5 Wet- en regelgeving $\quad 24$

$\begin{array}{ll}2.3 .6 \text { Biodiversiteit } & 24\end{array}$

3 Mogelijkheden en onmogelijkheden voor hoogwaardige toepassingen van hout uit landschap

3.1 Wat zijn hoogwaardige toepassingen van hout uit landschap? 25

$\begin{array}{lll}3.1 .1 & \text { Kenmerken van hout uit landschap } & 25\end{array}$

3.1.2 Classificatie van hout toepassingen naar functionaliteit $\quad 25$

3.1.3 Toepassingen van hout uit landschap 26

$\begin{array}{lll}4 & \text { Handelingsperspectief } & 31\end{array}$

4.1 Discussie 31

4.2 Acties richting hoogwaardiger inzet $\quad 32$

$5 \quad$ Conclusies $\quad 35$

$\begin{array}{ll}\text { Literatuur en referenties } & 36\end{array}$

Bijlage 1 Voorbeeld van een uitwerking van de beoordelingsmatrix $\quad 39$

Bijlage 2 Samenstelling klankbordgroep en deelnemers workshop $\quad 41$ 



\section{Verantwoording}

Rapport: 2991

Projectnummer: 5200045540

Wageningen Environmental Research (WENR) hecht grote waarde aan de kwaliteit van zijn eindproducten. Een review van de rapporten op wetenschappelijke kwaliteit door een referent maakt standaard onderdeel uit van ons kwaliteitsbeleid.

Akkoord Referent die het rapport heeft beoordeeld,

functie: Hoogleraar Europees Bos

naam: $\quad$ prof. dr. ir. GJMM Nabuurs

datum: 15 februari 2020

Akkoord teamleider voor de inhoud,

naam: dr. ir. NAC Smits

datum: 21 februari 2020 


\section{Samenvatting}

Doel van dit onderzoek is inzicht te krijgen in de kansen en belemmeringen van hoogwaardige toepassing van hout uit landschap en het handelingsperspectief te beschrijven om hoogwaardiger toepassing van deze biomassareststroom te bewerkstelligen. Hout uit het landschap wordt nu vooral voor energieproductie (elektriciteit en warmte) ingezet. Dit wordt als een relatief laagwaardige toepassing gezien, hoewel er grote verschillen zijn binnen deze toepassing: van inefficiënt en vies tot relatief schoon en efficiënt.

Er zijn veel obstakels om hout uit landschap hoogwaardiger in te zetten, bijvoorbeeld voor producten of voor papier en ook voor de productie van chemicaliën, zoals de relatief lage kwaliteit, de geringe uniformiteit, de lage volumes, de versnippering van de afzet over vele soorten ketens van hout uit landschap en het gebrek aan afzetmogelijkheden in Nederland. Voor afzet naar hoogwaardige toepassingen moet dit hout bovendien voldoen aan andere en vaak hogere eisen. Het advies is om de komende jaren die richting op te gaan, door tussenproducten te maken die zowel voor energie nu als later voor hoogwaardigere toepassingen zijn te gebruiken. Samenwerking is hierbij van groot belang: tussen landschapsbeheerders onderling en met andere spelers in de keten, zoals de aannemers, de huidige en toekomstige afnemers en ook met financiers en technologieproducenten.

Er moet duidelijkheid komen over wat er onder hoogwaardigheid wordt verstaan, zodat hier ook op kan worden afgerekend. Het is belangrijk te beseffen dat hierbij ook efficiëntie en andere impactcategorieën als broeikaseffect meegenomen worden (in bijlage 2 staat een aanzet voor zo'n systeem). Biomassawerven zijn een middel om het kwaliteitsprobleem op te lossen en tot grotere hoeveelheden geschikte volumes te komen. Op deze werven wordt de biomassa geclassificeerd en/of voorbewerkt tot uniforme tussenproducten. Zo kunnen de kleine volumes landschapshout meeliften met de andere houtstromen. Bij de classificatie moet goed worden samengewerkt met afnemers en producenten van houtige biomassa.

Ook de afnemers van houtige biomassa hebben een uitdaging. Het is mogelijk om hoge eisen aan biomassa te stellen, maar de kans dat er geconcurreerd wordt met hoogwaardiger toepassingen is dan groot. Het is belangrijk dat robuuste technologieën ontwikkeld worden die ook geschikt zijn voor verwerking van lagere kwaliteit hout. Dit betekent investeringen in productieprocessen en voorbewerkingsstappen.

De overheid kan ook als launching customer bovenstaande ontwikkelingen versnellen, door bij de inkoop van tal van producten slimme eisen te stellen aan de herkomst van de inputmaterialen ervan.

In hoofdstuk 2 wordt een beeld geschetst van de huidige afzet van houtige biomassa uit landschap en de potentie. Hier wordt ook een vooruitblik geschetst naar 2030 en 2050.

Hoofdstuk 3 gaat in op de mogelijkheden voor hoogwaardige toepassingen van hout uit landschap. Hier wordt een classificatie geschetst van houttoepassingen naar functionaliteit en wordt ingegaan op de toepassing van hout als zaaghout, vezeltoepassingen, monomere toepassingen en energietoepassingen.

In hoofdstuk 4 wordt het handelingsperspectief geschetst, waarbij negen actiepunten worden geadresseerd:

1. Richt het landschap zo in dat oogst van het hout met een hogere kwaliteit voor onder meer constructiehout en vezeltoepassingen mogelijk wordt.

2. Stimuleer dat het vrijkomende hout uit landschap zo hoogwaardig mogelijk wordt ingezet.

3. Ontwikkel een beoordelingssysteem voor hoogwaardigheid en impact van houtige biomassa.

4. Reken aannemers (en andere afnemers van hout) bij inzet van hout voor energietoepassing af op efficiëntie en evt. uitstoot.

5. Classificeer hout uit landschap op verschillende kwaliteiten via fysieke en digitale biomassawerven.

6. Creëer een marktsysteem voor afzet van hout en dus ook hout uit landschap.

7. Samenwerking tussen landschapsbeheerders, biomassawerven en potentiële afnemers.

8. Overheid als launching customer. 


\section{Summary}

The goal of this project is to gain insights in the potential of high-value application of woody biomass from landscape elements and to describe a framework for action to unlock the potential of this residual flow of biomass. Woody biomass from landscape elements is now primarily used for energy production (electricity and heat). This application is regarded as a relatively low-value application, although there are big differences within the application: ranging from inefficient and dirty to relatively clean and efficient.

There are many obstacles on the route to a high-value application of woody biomass from landscape elements to e.g. longlived products, paper and the production of chemicals. This includes the relatively low quality, the lack of uniformity, the low volumes, many different supply chains and the lack of a market for woody biomass in the Netherlands. Moreover, the biomass has to meet strict requirements. The advice is to create products of the biomass that can now be used for energy generation and can be used for high-value applications in the future. Cooperation is key: between the managers of landscape elements and also with other actors in the supply chain: e.g. contractors, the current and prospective buyers and also with financers and technology companies.

A clear definition of high-value applications has to be created, in order to set boundaries. It is important to realise that efficiency and other impact factors such as greenhouse gas emissions will be taken into account (annex 2 comprises a draft for a potential system).

Biomass hubs can be a mean to solve the quality issue of biomass and to collect larger volumes. The biomass can be segregated into different quality classes and can be pretreated to products of uniform quality. In this way, small volumes of woody biomass can be integrated in other biomass flows. A good cooperation with buyers and producers is key in segregating the biomass in different quality classes.

There is also a challenge for the buyers of woody biomass. Setting high standards for the biomass is possible, but this will increase the chance of competition with higher-value applications. It is important that robust technologies will be developed to cope with the pretreatment of biomass of lower quality. This involves investments in production processes and pretreatment protocols. The government can stimulate the mentioned developments as launching customer, by setting goals at using sustainably produced materials for their own needs.

Chapter 2 identifies and quantifies the current flows of woody biomass from landscape elements and the potential volumes that can be harvested. The chapter also gives a prospect for 2030 and 2050. Chapter 3 elaborates the possibilities of high-value applications of woody biomass from landscape elements. The applications are classified by their functionality. The chapter further examines the application of woody biomass as lumber, pulpwood, monomers and for energy generation.

Chapter 4 describes a framework for action and addresses nine actions:

1. Design the landscape elements in a manner that enables the harvest of high quality wood, suitable for high-value applications;

2. Stimulate the use of woody biomass from landscape elements for high-value applications;

3. Develop an assessment rubric for high-value applications and the impact of woody biomass;

4. Take efficiency and potential emissions of the application of woody biomass for energy generation into account, both for contractors and buyers;

5. Segregate the woody biomass from landscape elements into different quality classes by means of physical present biomass hubs and digital biomass hubs;

6. Set up a market for woody biomass from landscape elements;

7. Stimulate cooperation between managers of landscape elements, biomass hubs and potential buyers;

8. Develop a role for the government as launching customer. 


\section{Achtergrond en doel}

\subsection{Achtergrond}

In het rijksbrede programma 'Nederland Circulair in 2050' schetst het huidige kabinet de ontwikkeling naar een circulaire economie. In het Uitvoeringsprogramma Circulaire Economie 2019-2023 zijn voor het bereiken van de doelstellingen in 2050 verschillende prioritaire ketens bepaald. Een daarvan is 'Biomassa en Voedsel'. Vanuit deze context heeft het ministerie van Infrastructuur en Waterstaat een beleidsondersteunende opdracht uitgezet bij Rijkswaterstaat. Het doel van deze opdracht is 'inzicht krijgen en handelingsperspectief creëren in de vraag en afzet van duurzame biomassa in een circulaire economie'. In overleg met het ministerie van I\&W heeft Rijkswaterstaat ervoor gekozen om dieper in te gaan op de biomassareststroom vers hout uit landschap binnen Nederland en de kansen en belemmeringen voor een meer hoogwaardige toepassing van deze reststroom (hoogwaardiger dan inzet voor alleen energie).

Hout uit landschap is een van de biomassastromen die, net als berm- en natuurgras, als 'ongebruikt potentieel' wordt aangemerkt door PBL. De toepassing in Nederland van hout uit landschap is, naast bodembedekking en -verbetering, momenteel voornamelijk energetisch. Vanuit de ambitie om te komen tot een circulaire economie wil het ministerie van I\&W zicht krijgen op de kansen en belemmeringen voor een hoogwaardigere toepassing van hout uit landschap.

\subsection{Doel}

Dit onderzoekproject heeft als doel inzicht te krijgen in de kansen en belemmeringen van hoogwaardige toepassing van hout uit landschap en het handelingsperspectief te beschrijven om hoogwaardigere toepassing van deze biomassareststroom te bewerkstelligen. Het onderzoek bestaat uit twee hoofdonderdelen:

1. Beschrijving van de huidige situatie (hoofdstuk 2).

Hier wordt beschreven hoeveel hout er uit landschap wordt geoogst, hoe dit nu wordt benut en hoe de hierbij behorende ketens functioneren.

2. Verkenning hoogwaardige inzet en handelingsperspectief (hoofdstuk 3 en 4). Hier worden ook de toekomstige ontwikkelingen meegenomen en de toekomstige hoogwaardige toepassingen verkend. Bestaande en toekomstige toepassingen worden op impact en hoogwaardigheid gescoord, nu en in de toekomst. Voor de verschillende toepassingen worden mede op basis van interviews bestaande inzichten, belemmeringen, kansen en handelingsperspectief geschetst. De focus is op nu (2019), de nabije toekomst (2030) en de verder weg gelegen toekomst (2050).

\section{$1.3 \quad$ Methode}

De data over beschikbaarheid en huidige toepassingen worden verzameld uit literatuur- en deskresearch. Bij de verkenning van de hoogwaardigere toepassingen wordt gebruikgemaakt van expert judgement van een aantal marktpartijen en experts van binnen en buiten Wageningen University \& Research en van data beschikbaar over experimenten/pilots in Nederland en Europa. Op 28 november 2019 zijn de tussenresultaten en het handelingsperspectief besproken in een workshop met ca. 20 vertegenwoordigers van het werkveld. Op 23 januari 2020 zijn de resultaten gepresenteerd aan de klankbordgroep. De ingebrachte punten en ideeën bij deze bijeenkomsten zijn zo goed mogelijk verwerkt. In bijlage 2 zijn de samenstelling van de klankbordgroep en de lijst van deelnemers aan de workshop opgenomen. 


\subsection{Karakterisering houtige biomassa uit landschap}

Houtige biomassa uit landschap is grotendeels afkomstig van bomen en van struiken. Figuur 1 geeft de verschillende houtige onderdelen weer van een boom. Het betreft een vereenvoudigde weergave zo kan stamhout worden onderverdeeld in schors, spint- en kernhout. Stamhout kan verwerkt worden als rondhout, wat bijvoorbeeld voor constructietoepassingen gebruikt wordt. Takhout kan bijvoorbeeld verwerkt worden tot houtchips (houtsnippers). Wanneer er geen onderscheid gemaakt hoeft te worden naar een specifiek houttype, wordt het geoogste hout in dit rapport omschreven als 'houtige biomassa'.

Het deel van de boom dat het interessantst is voor hoogwaardige toepassingen is stamhout. Daarom wordt er in productiebossen gestuurd op bomen met knoestvrije stammen, die lang en recht zijn zonder zijtakken onderin. Bomen in landschapselementen (met name lijnvormige en puntvormige elementen) hebben relatief meer takken dan bosbomen, omdat ze meer ruimte hebben en ook meer in de breedte kunnen uitgroeien. Doordat de bomen in landschapselementen over het algemeen minder dicht op elkaar staan, wordt de hoogtegroei niet zo gestimuleerd als in bosverband en is de stam vaak minder recht. Hierdoor is het aandeel stamhout van bomen in landschapselementen geringer dan bij bomen in bossen (bij deze laatste afhankelijk van boomsoort $70-85 \%$ stamhout). Zie figuur 1 voor een schematisch overzicht van de verdeling van het hout over de boom in stamhout en takhout. Daarnaast staan er meer loofbomen dan naaldbomen in landschapselementen, terwijl het stamhout van naaldboomsoorten zoals grove den en Douglasspar juist veelgevraagd is in de houtindustrie.

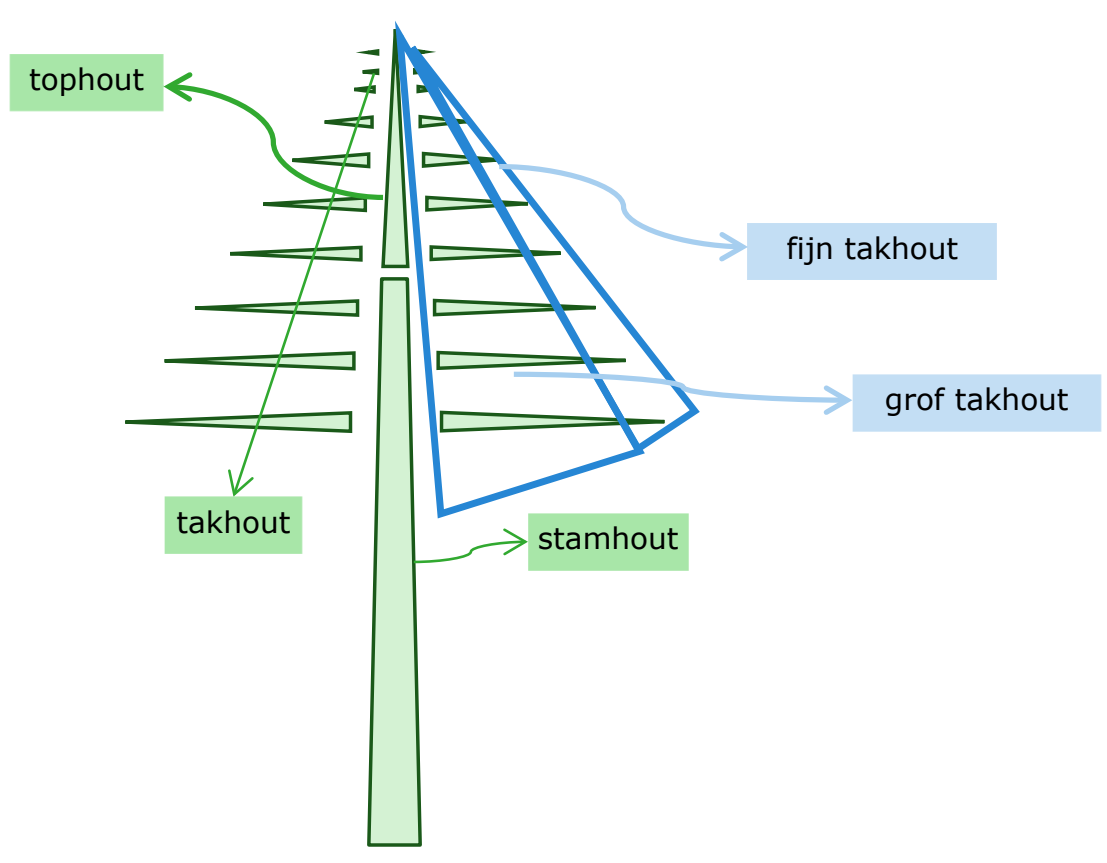

Figuur 1 Typen hout van de boom die in deze studie in beschouwing worden genomen (De Vries et al., 2019).

De biomassa is afkomstig uit een scala van verschillende landschapselementen. In figuur 2 worden de meest voorkomende types landschapselementen weergegeven. 

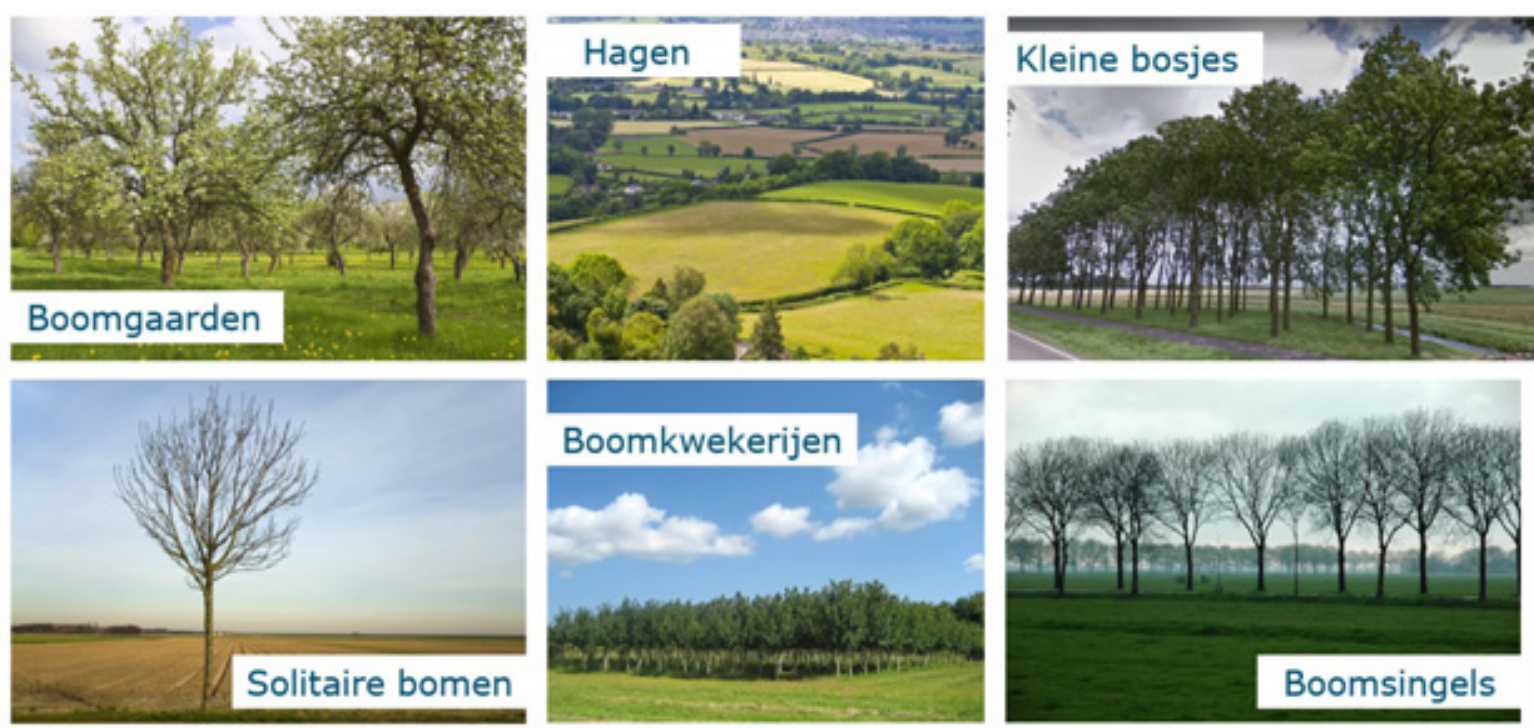

Figuur 2 Voorbeelden van verschillende houtige landschapselementen (bron: Beeldbank WUR).

Een ander belangrijk verschil tussen bomen in bossen en die in landschapselementen is het beheer. Voor een groot deel van de bossen wordt de productie van hout efficiënt georganiseerd, primair gericht op de verwaarding van het vrijkomende hout. In landschapselementen is daar vaak weinig aandacht voor. Ook komt het hout

door de schaal en de verspreide ligging van landschapselementen zo vrij dat het minder rendabel is om hout te oogsten. Het aandeel stamhout is tevens kleiner en omdat een belangrijk deel van het vrijkomende hout vrijkomt bij snoeimaatregelen, is het aandeel takhout bij de vrijkomende houtige biomassa hoog.

\section{$1.5 \quad$ Projectafbakening}

Het project richt zich op de beschikbaarheid van houtige biomassa uit het Nederlandse landschap. Buiten beschouwing blijft houtige biomassa uit bossen en uit bebouwd gebied. Houtige biomassa uit de Nederlandse gemeenten in het Caraïbisch gebied blijft eveneens buiten beschouwing. Biomassa in naalden en blad (meestal geen houtige biomassa) en ondergrondse houtige biomassa (wortels) blijven buiten beschouwing, evenals niet-houtige biomassa, zoals maaisels. 


\section{$2 \quad$ Huidige afzet houtige biomassa uit landschap}

\section{$2.1 \quad$ Schatting huidige afzet}

In 2017 werd ongeveer 185 kton ds aan houtige biomassa uit het Nederlandse landschap geoogst en verhandeld (Probos, 2018). Houtige biomassa uit landschap maakt 30\% uit van de totale bij de bron ingekochte hoeveelheid verhandelde biomassa, naast bos (29\%) en de bebouwde omgeving (41\%). Dit is exclusief import.

Van de totale hoeveelheid in Nederland geproduceerde biomassa wordt $43 \%$ geëxporteerd (Oldenburger \& Boosten, 2019). Naar verwachting ligt dit percentage voor houtige biomassa uit landschap iets lager, omdat er vooral shreds (grovere houtsnippers, 10-200 mm) worden geëxporteerd die vrijkomen bij omvormingen in bos en stedelijk groen.

De houtige biomassa die wordt geoogst bij landschapsonderhoud wordt grotendeels toegepast voor energetische doeleinden. Dit kan in particuliere kachels en open haarden zijn of in binnen- of buitenlandse energiecentrales. De verschillende stromen zijn moeilijk te kwantificeren. Dit komt enerzijds omdat er geen goede statistieken worden bijgehouden specifiek voor de afzet van houtige biomassa uit landschap, waardoor er weinig tot geen kengetallen zijn. Anderzijds zijn er belangrijke afzetkanalen waarvan geen geregistreerde gegevens zijn, omdat ze buiten de markt om verlopen (zoals het verbranden van biomassa in het open veld, waarover geen centrale landelijke gegevens worden bijgehouden). Op basis van literatuuronderzoek, interviews en expert judgement zijn de verschillende afzetkanalen echter wel geschat en gekwantificeerd voor dit rapport (zie tabel 1).

Het gedeelte van de bijgroei dat niet wordt geoogst en de hoeveelheid geoogste biomassa die niet wordt afgevoerd, zijn niet meegenomen in tabel 1 . Naar verwachting wordt maar een klein deel van de geoogste biomassa in het landschap achtergelaten. Het gedeelte van de bijgroei dat niet geoogst wordt zou wel groot kunnen zijn, gezien de vaak achterstallige staat van onderhoud in veel landschapselementen (Snepvangers et al., 2013). 


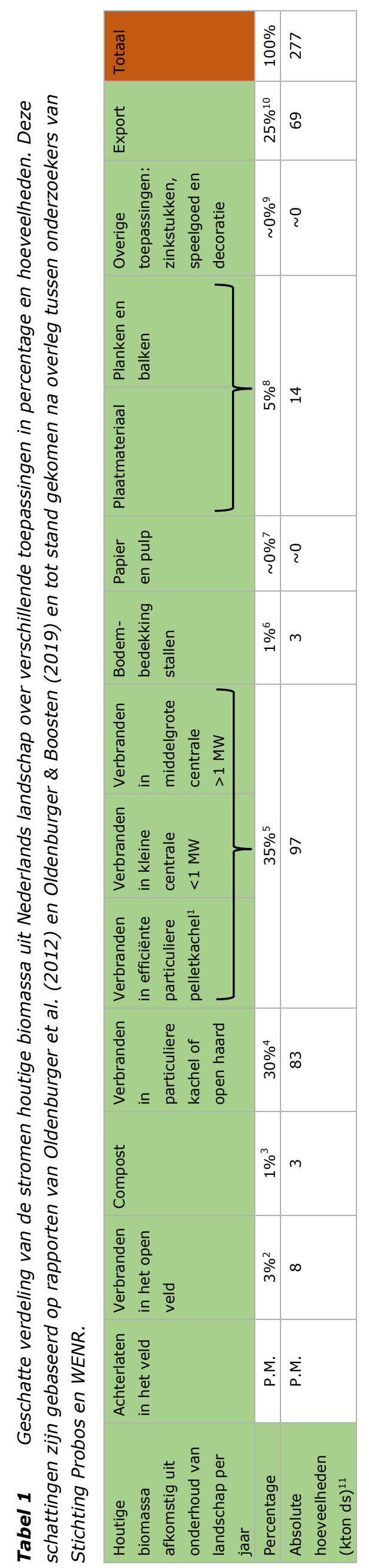

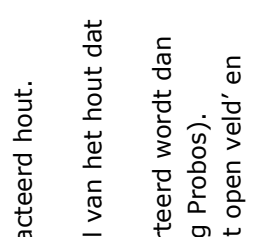

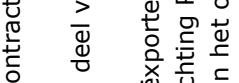

过

ฮे

पु山

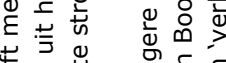

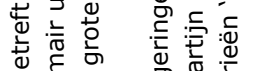

㟧

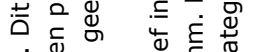

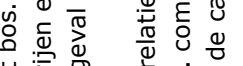

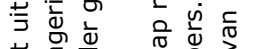

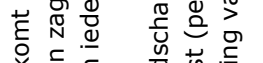

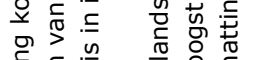

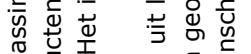

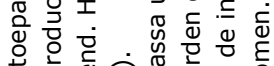

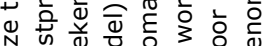

ปับ

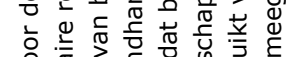

>

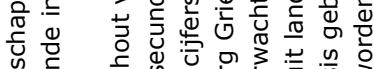

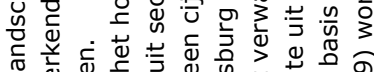

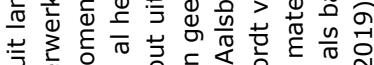

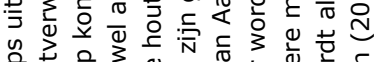

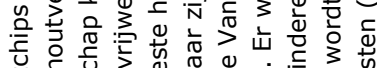

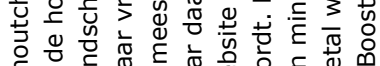

ธ ᄃ

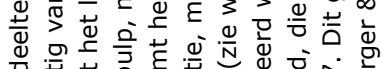

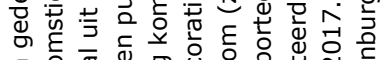

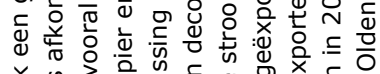

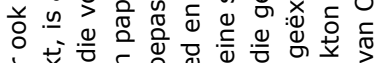

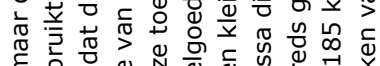

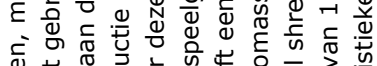

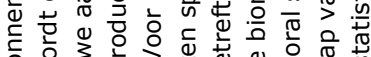

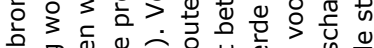

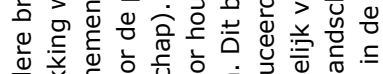

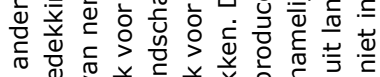

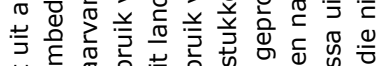

节密

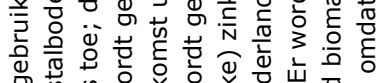
जि

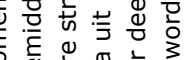

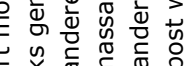

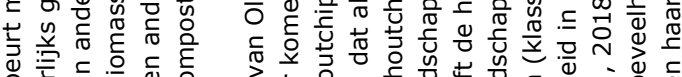

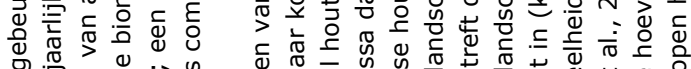

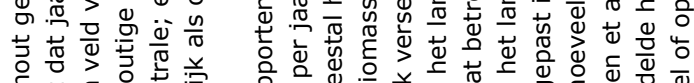

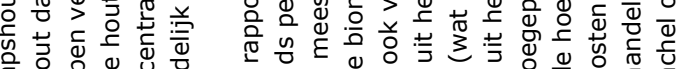

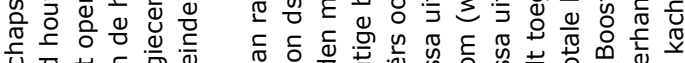

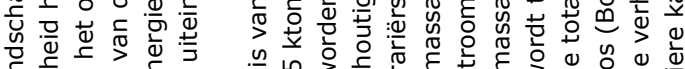

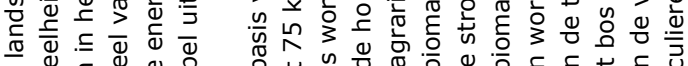

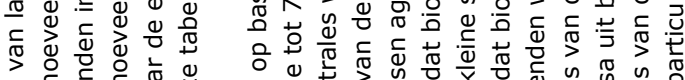

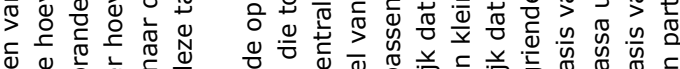

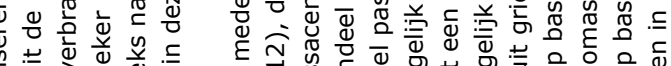

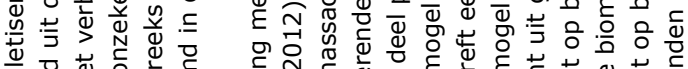

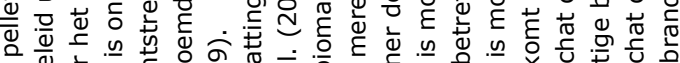

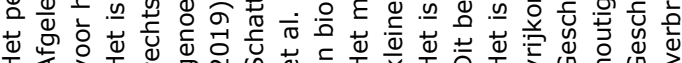




\subsubsection{Reflectie schatting huidige afzet}

Grofweg vallen de afzetkanalen voor houtige biomassa uit het Nederlandse landschap in te delen in drie categorieën:

- Niet-verhandelde biomassa die lokaal wordt toegepast

- Binnenlands verhandelde biomassa

- Geëxporteerde biomassa

Niet-verhandelde biomassa die lokaal wordt toegepast

De stroom biomassa uit landschap die lokaal wordt toegepast, is moeilijk te kwantificeren. Dit komt omdat landelijke gegevens over lokaal biomassaverbruik geen onderscheid maken naar de herkomst van de biomassa (landschap, stedelijk, bos). Er is daarom bij het bepalen van de omvang van enkele stromen in tabel 1 gebruikgemaakt van expert judgement. Het betreft hier in ieder geval in de meeste gevallen laagwaardige toepassingen. Bij paasvuren wordt jaarlijks bijvoorbeeld vooral in oostelijke provincies veel houtige biomassa uit landschap verbrand.

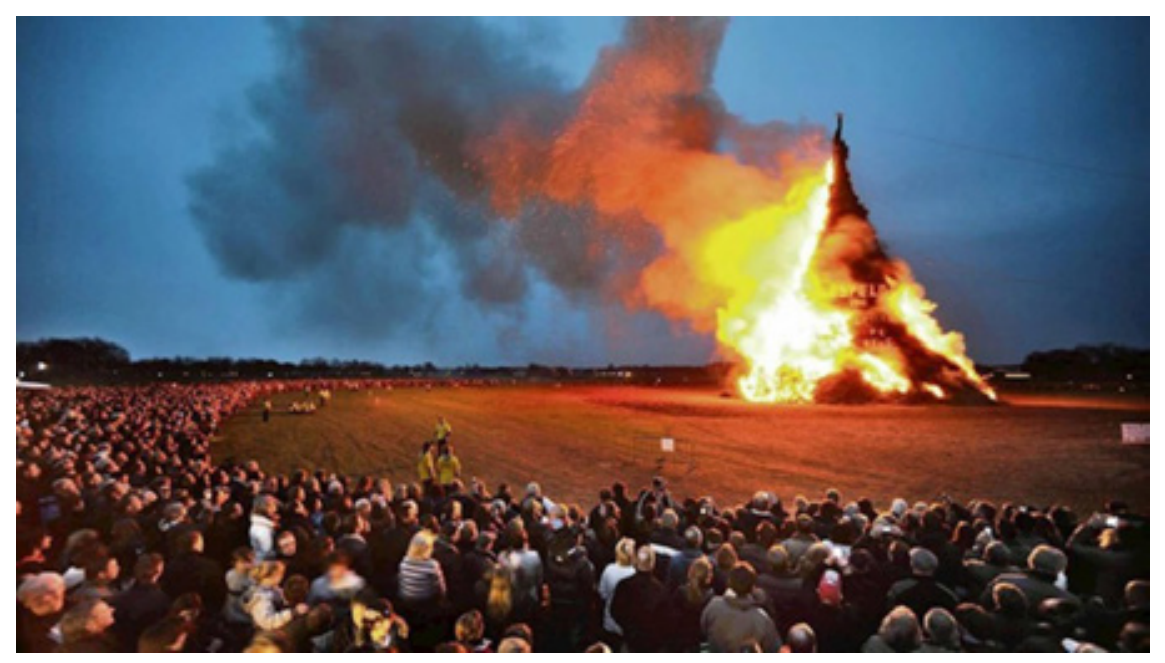

Figuur 3 Paasvuur bij Espelo (bron: RTV Oost).

Daarnaast wordt houtige biomassa ook in particuliere kachels en open haarden verstookt, waarbij de energieomzetting meestal weinig efficiënt is.

Kwantificering van deze stroom is lastig, omdat de biomassa veelal niet verhandeld en geregistreerd wordt, maar direct door landschapsbeheerders wordt gebruikt of wordt doorgegeven aan bijvoorbeeld buren.

\section{Binnenlands verhandelde biomassa}

De belangrijkste toepassing voor binnenlands verhandelde biomassa is energieopwekking. Er zijn geen exacte cijfers bekend over de mate waarin houtige biomassa uit landschap wordt afgezet bij verschillende grootteklassen van biomassacentrales. $\mathrm{Er}$ is daarom één getal opgenomen voor de totale afzet naar biomassacentrales. Het kan wel vergeleken worden met de cijfers van de totale hoeveelheid houtige biomassa die gebruikt wordt voor energieopwekking (dus ook afkomstig uit bos en stedelijk groen). Hieruit blijkt dat in 2017 65\% van de biomassa bij biomassacentrales werd afgezet en 35\% bij bedrijven met biomassaketels (Probos, 2018).

\section{Geëxporteerde biomassa}

Van de hoeveelheid houtige biomassa uit landschap die wordt geëxporteerd, wordt geschat dat $90 \%$ wordt gebruikt voor energieopwekking. 10\% wordt afgezet voor andere doeleinden, zoals het produceren van spaanplaat (pers. comm. Martijn Boosten, Stichting Probos). 


\subsubsection{Regionale beschikbaarheid}

In het rapport 'Beschikbaarheid van Nederlandse verse houtige biomassa in 2030 en 2050' van Boosten et al. (2018) is het biomassapotentieel uit het landschap per provincie geschat. Onderstaande tabel geeft het houtig biomassapotentieel uit het landschap weer per provincie per jaar.

Tabel 2 Houtig biomassapotentieel per provincie.

\begin{tabular}{ll} 
Provincie & Houtig biomassapotentieel (kton ds/jr) \\
Groningen & 5,6 \\
\hline Friesland & 14,7 \\
\hline Drenthe & 14,7 \\
\hline Overijssel & 27,0 \\
\hline Flevoland & 7,5 \\
\hline Gelderland & 46,8 \\
\hline Noord-Holland & 11,4 \\
\hline Utrecht & 12,6 \\
\hline Zuid-Holland & 19,3 \\
\hline Zeeland & 12,4 \\
\hline Noord-Brabant & 46,8 \\
\hline Limburg & 22,6
\end{tabular}

Het blijkt dat met name de provincies op de hoger gelegen delen van het land een relatief wat hoger biomassapotentieel hebben.

\section{Regionale Energie Strategieën}

Momenteel wordt er in dertig regio's een Regionale Energie Strategie (RES) uitgewerkt. Dit gebeurt in het kader van het Nationaal Programma Regionale Energie Strategie (NP RES), dat wordt getrokken door VNG, IPO, de Unie van Waterschappen, door het ministerie van Economische Zaken en Klimaat en door het ministerie van Binnenlandse Zaken en Koninkrijksrelaties. Het doel van de RES is om regionaal te kunnen afstemmen hoe er moet worden voorzien in de opwekking van duurzame elektriciteit, warmtetransitie in de gebouwde omgeving en de daarvoor benodigde opslag en infrastructuur.

Bij het opstellen van de RES kunnen regio's de analysekaarten van het NP-RES gebruiken als hulpmiddel. Figuur 4 toont bijvoorbeeld de biomassapotentie (verbrandbare biomassa) voor de verschillende regio's. Op basis hiervan zou een voorspelling kunnen worden gedaan welke regio zich meer of minder op biomassa zal focussen in de RES. De RES zijn echter momenteel nog in ontwikkeling. Daardoor is het nog niet mogelijk om een uitspraak te doen over de rol van houtige biomassa uit landschap voor specifieke regio's. Het Rijk, IPO, Unie van Waterschappen en VNG hebben eind 2018 een handreiking geschreven als hulpmiddel voor de uitwerking van de regionale energiestrategieën (2018). In deze handreiking wordt aangegeven op welke wijze de beschikbare biomassa in de verschillende regio's (biomassa uit landbouw, bos, landschap en stad) kan worden ingezet. Naast reststromen wordt ook biomassateelt als optie aangegeven. Bij toepassingen wordt biomassa genoemd bij warmte en bij elektriciteit. 


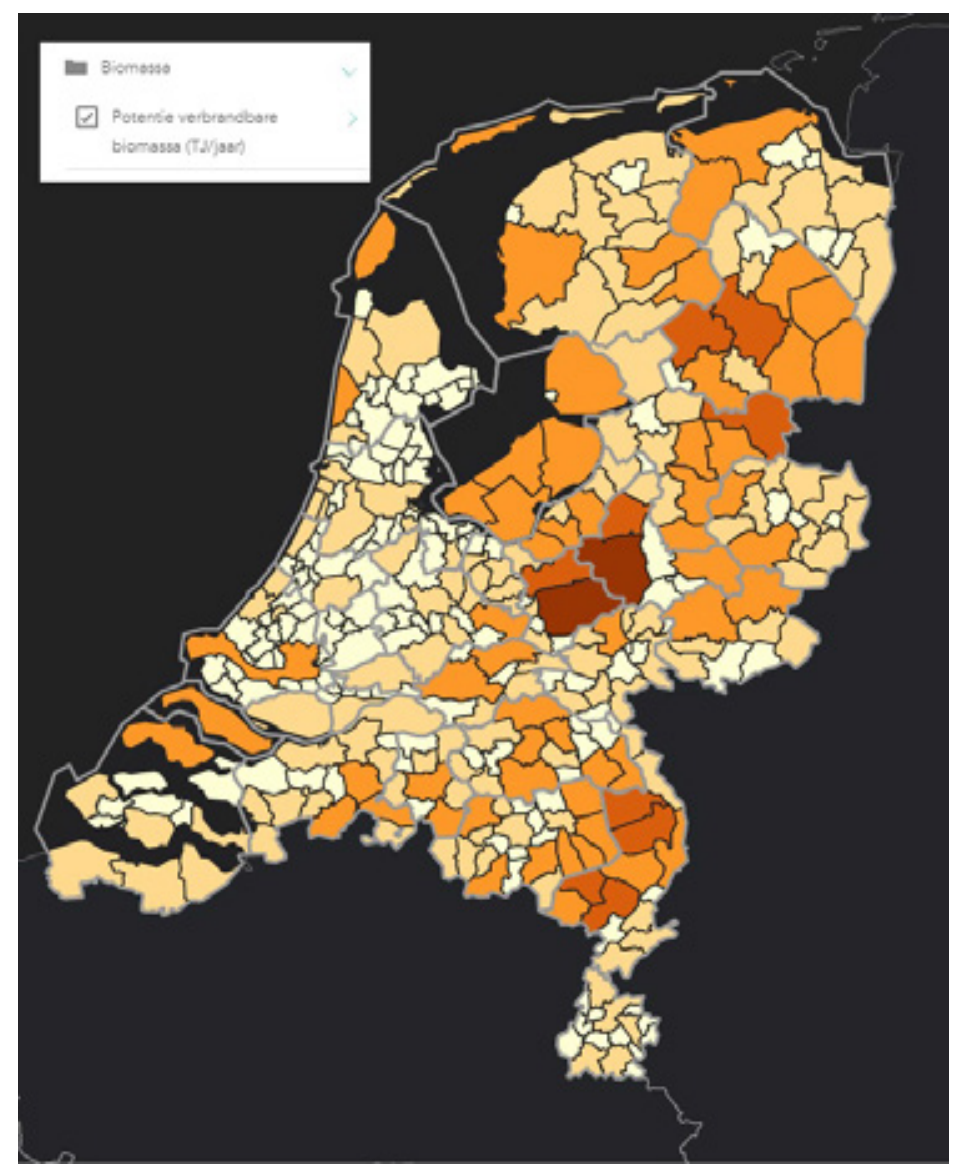

Figuur 4 Biomassapotentie per regio (bron: analysekaart NP-RES).

\subsubsection{Ketens}

Bij de ketens van houtige biomassa uit landschap zijn zeer veel partijen betrokken. Partijen zijn betrokken bij:

1. Eigendom en beheer van landschappelijke beplanting

2. Onderhoud en oogst

3. Transport van vrijkomende houtige biomassa

4. Verwerking van houtige biomassa

Voorts zijn er partijen vanuit bepaalde deelbelangen betrokken, zoals natuur- en landschapsbescherming, milieuorganisaties, cultureel erfgoed, recreatie, bewonersorganisaties etc. Tevens zijn diverse overheden als regelgever betrokken.

Per stroom zijn ketens vaak anders georganiseerd. Soms zijn ketens zeer kort, bijvoorbeeld bij een agrariër die eigenaar is van een beplanting. De agrariër kan zelf het onderhoud verzorgen en het materiaal gebruiken in een eigen installatie. Dit kan bijvoorbeeld dienen voor verwarming van eigen woning/bedrijfsgebouw of voor een productieproces. In bijlage 1 zijn enkele voorbeelden van ketens opgenomen. Tabel 4 toont voor verschillende types landschapselementen welke partijen eigenaar kunnen zijn en welke partijen het onderhouden. 
Tabel 4 Beschrijving eigendom/beheer en uitvoering per type landschapselement.

\begin{tabular}{|c|c|c|}
\hline Landschapselement & Eigendom/beheer & Uitvoering onderhoud \\
\hline Boomkwekerijen & Agrariërs & Agrariërs, loonbedrijf \\
\hline Fruitteelt: laagstam & Agrariërs & Agrariërs, loonbedrijf \\
\hline $\begin{array}{l}\text { Houtwallen, singels en } \\
\text { hagen, kleine bosjes }\end{array}$ & $\begin{array}{l}\text { Zeer divers: } \\
\text { - Overheden: gemeenten, provincies, RWS, } \\
\text { waterschappen } \\
\text { - Terreinbeherende organisaties (Provinciale } \\
\text { landschappen, Staatsbosbeheer, } \\
\text { Natuurmonumenten e.d.) } \\
\text { - Natuur- en landschapsbeheer (meestal } \\
\text { alleen beheer) } \\
\text { - Agrariër } \\
\text { - Particulier }\end{array}$ & $\begin{array}{l}\text { Zeer divers: } \\
\text { Eigen dienst overheid, ingehuurde aannemer, } \\
\text { onderaannemer, (ingehuurde) agrariër, } \\
\text { loonbedrijf, vrijwilligers (lokale natuur- en } \\
\text { vogelwacht, landschapsbeheer, particulier) }\end{array}$ \\
\hline Solitaire bomen & $\begin{array}{l}\text { Overheden (met name gemeenten, agrariërs, } \\
\text { particulieren }\end{array}$ & $\begin{array}{l}\text { Overheden (met name gemeenten), agrariërs, } \\
\text { particulieren }\end{array}$ \\
\hline
\end{tabular}

Voor de keten zijn ook de vervolgstappen downstream van belang: transport van de houtige biomassa naar de plaats van verwerking (soms na tussenopslag) en verwerking van de houtige biomassa.

In korte ketens kan de eigenaar/beheerder zelf voor transport en verwerking van de biomassa zorgen, bijvoorbeeld indien deze de geoogste biomassa transporteert naar het eigen erf en daar een eigen kachel of kleine biomassaketel staat. Er kunnen echter ook complexe ketens zijn, waarbij tussenhandel de biomassa opkoopt van de eigenaar of de uitvoerende aannemer, een transportbedrijf inschakelt voor het transport naar de plaats van verwerking en daar de houtige biomassa afzet aan de afnemer van de biomassa. Een goede ketenorganisatie is van belang. Als de afnemer bepaalde eisen aan het product stelt, zullen partijen eerder in de keten hier rekening mee moeten houden.

\subsection{Potentiële productie van hout en houtige biomassa uit het landschap}

\subsubsection{Huidige stand van zaken}

Voor de ontwikkelingen richting 2030 en 2050 is het belangrijk te kijken of de potentiële oogst uit het landschap nog vergroot/verbeterd zou kunnen worden (kwantiteit en kwaliteit). ${ }^{12}$ Daarbij wordt eerst gekeken naar de huidige bijgroei in de landschapselementen. De bijgroei van houtige biomassa in landschapselementen wordt geschat op basis van een kengetal voor de bijgroei per type landschapselement. Voor het bepalen van dit kengetal en voor het schatten van de arealen van de verschillende types landschapselementen worden gegevens en schattingen van de rapporten van De Vries et al. (2008) en Boosten et al. (2018) gebruikt.

Voor het bepalen van de potentiële oogst is een inschatting gemaakt op basis van een potentiële oogst van $100 \%$ van de gemiddelde jaarlijkse bijgroei. In de praktijk is het vrijwel onmogelijk om $100 \%$ van de bijgroei van de bovengrondse houtige biomassa te oogsten. In de meeste landschapselementen vindt onderhoud plaats met een veel lagere frequentie dan eenmaal per jaar. In de tussentijd verdwijnt een deel van de biomassa bijvoorbeeld door takval en rot en komt daardoor niet beschikbaar. Bij de berekening van de gemiddelde jaarlijkse bijgroei per ha is hiermee rekening gehouden. Daarom is een oogstniveau van $100 \%$ van deze bijgroei mogelijk. Zie tabel 5.

\footnotetext{
${ }^{12}$ De kwaliteit wordt in belangrijke mate bepaald door de toepassing.
} 
Tabel 5 Bijgroei, areaal en potentiële oogst per type landschapselement.

\begin{tabular}{|c|c|c|c|}
\hline Landschapselement & $\begin{array}{l}\text { Bijgroei } \\
\text { (ton ds/ha) }\end{array}$ & Areaal & $\begin{array}{l}\text { Potentiële oogst (afgerond } \\
\text { op } 100 \text { ton ds) }\end{array}$ \\
\hline Boomkwekerijen & $1,25^{13}$ & 23.470 & 29.300 \\
\hline Fruitteelt: klein fruit & 1,25 & 21.550 & 26.900 \\
\hline Houtwallen en singels & 4,50 & 2696 & 12.100 \\
\hline Kleine bosjes: naaldbos & 4,50 & 1574 & 7100 \\
\hline Kleine bosjes: populieren & $6,65^{14}$ & 339 & 2300 \\
\hline Kleine bosjes: gemengd bos & 4,50 & 2336 & 10.500 \\
\hline Kleine bosjes: griend & $9,00^{15}$ & $1213^{16}$ & 10.900 \\
\hline
\end{tabular}

\begin{tabular}{llll}
\hline Landschapselement & $\begin{array}{l}\text { Bijgroei } \\
\text { (ton ds/stuk) }\end{array}$ & Aantal & $\begin{array}{l}\text { Potentiële oogst (ton ds) } \\
\text { Solitaire bomen }\end{array}$ \\
\hline
\end{tabular}

TOTAAL ton ds

312.400

De potentiële oogst van houtige biomassa uit landschap wordt geschat op ruim $312 \mathrm{kton}$ ds. ${ }^{18}$ Ter vergelijking: in 2017 werd 617,5 kton ds houtige biomassa totaal geoogst in Nederland (uit bos, stedelijke omgeving en landschap samen) (Probos, 2018).

\subsubsection{Vooruitblik naar 2030 en 2050}

Er zijn meerdere ontwikkelingen die de komende jaren de oogst van houtige biomassa uit landschap positief of negatief kunnen beïnvloeden. De belangrijkste ontwikkelingen zijn:

- Toename vraag naar biomassa

- Toename aanplant van bomen en andere landschapselementen

- Verdwijnen van landschapselementen

\section{Toename vraag naar biomassa}

Biomassa is de grootste bron van duurzame energie in Nederland (CBS, 2019). Als gevolg van de afspraken die zijn gemaakt onder het Klimaatakkoord van Parijs, zal het percentage hernieuwbare energie de komende jaren moeten stijgen. Gezien de huidige rol van biomassa in de hernieuwbare energiemix, de opkomst van de biobased economy en de projecties van andere studies, is het waarschijnlijk dat de vraag naar biomassa de komende jaren nog verder zal stijgen (Mantau et al., 2010; Boosten et al., 2018b).

Een stijgende vraag naar biomassa kan als gevolg hebben dat de prijs ook omhooggaat. Dit kan ervoor zorgen dat een groter deel van het oogstbare potentieel wordt geoogst. Een deel van de houtige biomassa in landschap dat eerder niet rendabel geëxploiteerd kon worden, zou bij een hogere kostprijs wel benut kunnen worden.

Een onzekere factor is de maatschappelijke discussie over voor- en nadelen van de inzet van biomassa voor energie- en andere doeleinden voor het bereiken van de klimaatdoelstellingen. Sluijsmans \&

\footnotetext{
13 Meeusen-Van Onna MJG, Hoogeveen MW, Sengers H (1998). Groene reststromen in agroketens; Een beschrijving van de markt van organische reststromen uit de landbouw en de voedings- en genotsmiddelenindustrie.

14 Afgeleid uit de opbrengsttabellen van Jansen \& Oosterbaan (2018).

15 Tuinzing WDJ (1938). Verslag over het rijksgriendproefveld te Langbroek en de andere griendproefvelden van 1931 tot 1938. Dir. Landb. Den Haag.

16 TOP10NL-sept-2018.

17 Van het areaal 'grienden en hakhout' uit Boosten et al. (2018) is het areaal grienden van TOP10NL-sept-2018 afgetrokken om het areaal hakhout te bepalen.

18 Dit is wat hoger dan het door Probos (2018) genoemde cijfer voor de potentiële bijgroei van 238 kTon, met name omdat in deze studie wordt uitgegaan van een maximaal oogstniveau van gemiddeld $70 \%$ van de jaarlijkse bijgroei.
} 
Spijker (2019) geven een analyse van deze discussie. Een niet onbelangrijk verschil is dat de vrijkomende $\mathrm{CO}_{2}$ uit kolen vanuit fossiele ondergrondse bronnen aan de C-kringloop in atmosfeer, oceaan, biomassa en bodem wordt toegevoegd, terwijl de vrijkomende $\mathrm{CO}_{2}$ uit houtige biomassa onderdeel blijft van de laatstgenoemde kringloop. Belangrijk aspect is dan wel het toepassen van duurzaam landschapsbeheer. Naar aanleiding van het Klimaatakkoord wordt door het ministerie van I\&W het integrale duurzaamheidskader biomassa opgesteld, dat ingaat op deze discussie.

\section{Toename aanplant van bomen en andere landschapselementen}

Er worden verschillende initiatieven ontplooid om in de toekomst meer bomen aan te planten in Nederland. Het Actieplan Bos en Hout stelde zich bijvoorbeeld in 2016 ten doel dat er 100.000 hectare bos/houtige beplanting moet worden aangelegd in Nederland (Nabuurs \& Van den Briel, 2017). Ook vanuit het Klimaatakkoord wordt gesteld dat er geïnvesteerd moet worden in bosaanleg. Bij het implementeren van dit soort initiatieven wordt ook naar de mogelijkheden binnen landschapselementen gekeken. Binnen de klimaatenvelop Bos, Natuur en Hout wordt bijvoorbeeld onder andere gekeken naar het aanplanten van bomen langs infrastructuur. Ook zijn er in sommige provincies subsidies beschikbaar voor de aanleg en herstel van houtige landschapselementen. De implementatie van deze initiatieven zou op termijn kunnen zorgen voor een uitbreiding van het areaal landschapselementen. Hierdoor zou ook het potentiële oogstvolume toe kunnen nemen. Voorts kan er hierdoor meer oog voor de 'oogstbaarheid' van het landschap komen, waardoor nieuwe landschapselementen mogelijk zodanig worden aangelegd dat oogst gemakkelijker en tegen lagere kosten kan plaatsvinden.

\section{Verdwijnen van landschapselementen}

Het areaal van verschillende types landschapselementen is in de afgelopen decennia sterk afgenomen als gevolg van ruilverkaveling, verstedelijking en onvoldoende beheer (Kuiper, 2015; Baas \& Van Herwaarden 2016). Zo nam bijvoorbeeld het aantal cultuurhistorische lijnelementen met 48,4\% af in de periode 1900-2003 (Koomen et al., 2007). Meer dan de helft van de landschapselementen verkeert in een slechte staat en $16 \%$ wordt bedreigd (Snepvangers et al., 2013). Afbouw en vermindering van subsidies voor het beheer en herstel van landschapselementen helpen hierbij niet.

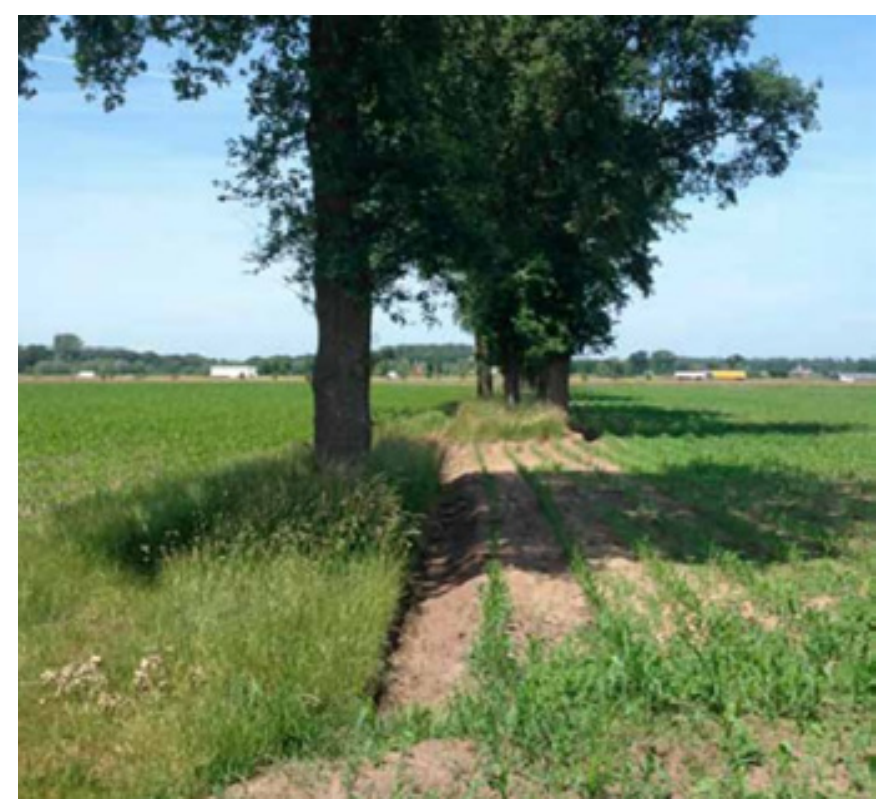

Figuur 5 Houtsingel wordt langzaam verdrukt door uitbreiding van een landbouwperceel (bron: Baas \& Van Herwaarden, 2016).

Planologisch gezien wordt een groot deel van de landschapselementen niet meer beschermd binnen de Wet natuurbescherming. Elementen met meer dan 20 bomen of groter dan 10 are mogen gekapt worden, mits dat gecompenseerd wordt met nieuwe aanplant. De compensatie mag echter ook plaatsvinden op een andere plek dan waar gekapt is (Van Doorn et al., 2016). 
Een andere reden dat landschapselementen en bomen verdwijnen, is verstedelijking, wegverbredingen en dergelijke. Daarnaast ligt de focus van het Agrarisch Natuurbeheer (ANLb) en het Plattelandsontwikkelingsprogramma (POP) op het vergroten van biodiversiteit en minder op de instandhouding van landschapselementen (PBL, 2019).

\section{Te verwachten ontwikkelingen op basis van huidige situatie en (ingezette) beleidslijnen 2030}

We leven in een schijnbaar steeds sneller veranderende wereld. Dat maakt tien jaar vooruitkijken lastig.

Naar verwachting zal het komende decennium de vraag naar biomassa voor energieopwekking blijven toenemen. Dit is echter ook afhankelijk van het wel of niet aanblijven van de SDE+-subsidie, die het stoken van biomassa voor energieopwekking subsidieert. Daarnaast kan de uitrol van de verschillende Regionale Energie Strategieën (waarover meer in paragraaf 2.1.3.1) nog een effect hebben op het gebruik van biomassa alsmede de maatschappelijke discussie over de voors en tegens van het gebruik van (houtige) biomassa.

De Visie Biomassa 2030 van het ministerie van Economische Zaken stelt dat biomassa op de lange termijn primair voor die toepassingen moet worden ingezet, waarvoor nauwelijks alternatieve, kosteneffectieve en duurzame bronnen beschikbaar zijn (ministerie van Economische Zaken, 2015). Dat betreft in ieder geval:

- Hoge temperatuur warmte voor de industrie

- Brandstoffen voor lucht- en scheepvaart

- Grondstoffen voor chemicaliën en materialen

De klimaattafel Landbouw en Landgebruik ziet mogelijkheden voor toepassingen in de keten van houtige biomassa afkomstig uit het beheer van de groene ruimte (Rijksoverheid, 2018). Hierbij wordt de $\mathrm{CO}_{2}$-vastlegging vergroot en de $\mathrm{CO}_{2}$-uitstoot ten gevolge van gebruik van alternatieve bouwmaterialen voorkomen.

\section{0}

Vooruitkijken naar 2050 gaat met nog meer onzekerheden gepaard. Het huidige beleid geeft aan richting 2050 naar een nagenoeg koolstofneutrale economie te streven. Om dat te bereiken, is het gebruik van de inhoudsstoffen van biomassa van wezenlijk belang. Voor het opwekken van hernieuwbare energie zijn ook veel andere bronnen beschikbaar, zoals zon, wind, aardwarmte etc. Daarom zal gebruik van inhoudsstoffen (moleculen?) van biomassa een belangrijkere rol kunnen gaan spelen. Ook het gebruik van het materiaal, hout, sluit daar goed op aan. Verbranding van biomassa voor energieopwekking ligt daarbij minder voor de hand.

\subsection{Reflectie op huidige prikkels voor de inzet van houtige biomassa uit landschap}

Na de Tweede Wereldoorlog is een groot deel van de landschapselementen verdwenen of door achterstallig onderhoud verwaarloosd. Een van de verklarende factoren voor deze 'degeneratie' van de landschappelijke houtige infrastructuur is de afgenomen behoefte en het gebruik van houtige producten uit deze elementen. Tegen deze trend in gaat de ontwikkeling van de laatste jaren, waarbij houtige biomassa onder meer vanuit het landschap een afzetkanaal vindt richting middelgrote biomassacentrales. De eerste hiervan opende in 2007 in Beetsterzwaag (Van Groningen et al., 2013).

In deze paragraaf wordt getracht een verklaring te vinden voor de huidige situatie. Er wordt daarom een analyse gemaakt van verschillende prikkels, die nu het ontsluiten van het biomassapotentieel uit landschap bepalen. 


\subsubsection{Kosten van de uitvoering}

De houtige landschapselementen liggen zeer verspreid in het landschap. Het meeste onderhoud vindt incidenteel plaats, waarbij slechts een klein deel van de aanwezige biomassa wordt 'geoogst', bijvoorbeeld door snoei, verwijderen van dode takken of verwijderen van een omgewaaide of verzwakte boom. Deze kleinschaligheid van het landschapsonderhoud maakt het logistiek lastig om een rendabele afvoer van houtige biomassa te realiseren. Voorts is het onderhoud er in eerste instantie op gericht om dit zo efficiënt mogelijk te organiseren en wordt niet altijd gelet op kwaliteitseffecten van vrijgekomen hout (bijv. voorkomen van contaminatie met gronddeeltjes).

Een deel van de houtige biomassa dat wordt geoogst, blijft achter op de oogstlocatie. Dit kan bijvoorbeeld zijn omdat de biomassa wordt gebruikt ter bedekking of verbetering van de bodem of voor het creëren van nest- en schuilgelegenheid voor vogels of insecten, maar waarschijnlijk meestal om economische redenen (lage kosten). Het achterlaten van geoogste biomassa is vaak een goedkope oplossing, maar kan alleen op plekken waar de functie van aangrenzende elementen niet in het gedrang komt. De inschatting is echter dat de hoeveelheid geoogste biomassa die achterblijft in het landschap hierdoor relatief veel kleiner is dan bijvoorbeeld bij bosbeheer.

In sommige gevallen wordt de biomassa ter plekke verbrand met een ontheffing (persoonlijke communicatie Irma Corten, Zilverberg Advies). Bij de fruitteelt is het gebruikelijk om snoeihout te verbranden. Bij onderhoud in andere type landschapselementen wordt er incidenteel biomassa verbrand. Wetgeving wat betreft verbranden van snoeihout is gedecentraliseerd naar gemeenten. De gemeenten geven ontheffingen, mits aan de vastgestelde voorwaarden wordt voldaan. De voorwaarden verschillen per gemeente, maar kunnen bijvoorbeeld betrekking hebben op het volume dat verbrand wordt, de periode waarin het verbrand wordt en de herkomst van de biomassa. Het storten van houtige biomassa buiten inrichtingen is verboden.

\subsubsection{Eigen gebruik}

Landschapselementen zoals houtwallen en singels worden vaak beheerd door agrariërs. De houtige biomassa die vrijkomt bij het onderhoud van deze elementen wordt veelal gebruikt voor het stoken in de eigen particuliere of bedrijfskachels. Dit is financieel aantrekkelijk, omdat zo bijvoorbeeld wordt bespaard op aardgas. De kosten van aardgas per energie-inhoud zijn flink hoger (onder meer door energiebelasting) dan die van hout(chips). Dit punt speelt vooral bij kleingebruikers, aangezien voor grootverbruikers een veel lagere energiebelasting geldt.

\subsubsection{Subsidie}

De Stimulering Duurzame Energieproductie (SDE+) maakt het aantrekkelijker om houtige biomassa af te zetten voor energieproductie. Ook voor installaties die geen SDE ontvangen kan energieproductie aantrekkelijk zijn, omdat het ten opzichte van aardgas per energie-eenheid meestal goedkoper is. Ook bij hoogwaardigere toepassingen ontstaan er residuen die voor energie zijn toe te passen en hier kan SDE+-subsidie stimulerend werken. Daar waar er wel concurrentie bestaat tussen hoogwaardige toepassingen en huidige energietoepassingen met SDE+-subsidie zou dit de hoogwaardigere toepassing in theorie kunnen beperken.

\subsubsection{Sociaal-cultureel, samenwerking}

Jaarlijks worden er verspreid over Nederland ten tijde van Pasen meer dan honderd paasvuren ontstoken. Het houden van paasvuren is verboden, maar er mag op grond van artikel 10.63 tweede lid Wet milieubeheer een ontheffing worden verleend door de gemeente. Zeker in oostelijke provincies wordt hiervoor ook houtige biomassa uit landschapsonderhoud gebruikt. Het zou interessant zijn als het inzamelenthousiasme voor deze stroom ook voor andere hoogwaardige toepassingen kan worden bereikt. In sommige regio's is daar ook al succes mee bereikt door het opzetten van geslaagde regionale ketens voor houtige biomassa uit landschapsonderhoud. De Vereniging Agrarisch Landschap Achterhoek (VALA) coördineert via de Coöperatie Achterhoeks Streekhout het beheer van landschapselementen (persoonlijke communicatie Dick Looman, VALA). Door deze grotere schaal kon 
een contract worden gesloten met ForFarmers voor het aanleveren van biomassa ten behoeve van een biomassacentrale. De vereniging Noardlike Fryske Wâlden (NFW) heeft dit met een vergelijkbaar initiatief (Streekhout) geprobeerd, maar dit kwam niet tot een rendabele exploitatie, mede door de lage prijs van concurrentie van aanbod van houtige biomassa uit Duitsland en Denemarken.

\subsubsection{Wet- en regelgeving}

De Wet milieubeheer stelt zekere beperkingen aan de toepassing van bij het onderhoud van landschappelijke beplantingen vrijkomende biomassa. Zo is het verboden om de biomassa te storten, anderszins op te slaan of te verbranden buiten een inrichting. Hiervoor mogen gemeenten (voor verbranden) of provincies (anderszins opslaan en storten) echter ontheffingen verlenen, zoals gebeurt bij het verbranden van houtige biomassa uit landschapsonderhoud in het open veld. Gelet op de complexiteit van dit onderwerp wordt het onderwerp wet- en regelgeving hier verder niet behandeld.

\subsubsection{Biodiversiteit}

In sommige gevallen wordt er gekozen voor het achterlaten van (een deel van de) houtige biomassa in het landschap voor biodiversiteitsdoeleinden. Staand of liggend dood hout is een belangrijke habitat voor verschillende vogel-, insecten- en zoogdiersoorten. Dit is een belangrijk aspect bij de landschapselementen die worden beheerd door terreinbeherende natuur- en landschapsorganisaties, maar ook veel particuliere landgoederen, overheden en bijvoorbeeld agrarische natuurverenigingen hebben beleidsdoelstellingen op dit vlak. 


\section{$3 \quad$ Mogelijkheden en onmogelijkheden voor hoogwaardige toepassingen van hout uit landschap}

\subsection{Wat zijn hoogwaardige toepassingen van hout uit landschap?}

\subsubsection{Kenmerken van hout uit landschap}

Uit landschap in Nederland komt veel hout vrij dat variabel is in samenstelling, vergeleken met hout uit bossen (zie hoofdstuk 2). Het bestaat voornamelijk uit verschillende soorten loofhout. Het bestaat - vergeleken met hout uit bossen - voor een groter deel uit tak- en tophout dat relatief veel bast bevat en daarmee dus ook veel nutriënten, zoals kalium, stikstof, calcium etc. Verder komt het hout zeer verspreid en per locatie meestal in kleine hoeveelheden vrij. De productie van het hout uit het landschap is een functie van het onderhoud. Het zal dus moeilijker zijn om in te spelen op een specifieke vraag. Alleen bij bijvoorbeeld grienden vindt nog op kleine schaal gerichte productie van houtige biomassa plaats, zij het niet op commerciële schaal.

\subsubsection{Classificatie van hout toepassingen naar functionaliteit}

Wij hebben een simpele classificatie opgesteld om hoogwaardigheid te definiëren.

De classificatie bestaat uit drie indicatoren.

De eerste indicator bestaat uit vijf trappen van functionaliteit:

4. Houttoepassing (meubels, bouwen, klompen)

3. Vezeltoepassing (papier/pulp, stalstrooisel)

2. Monomeren/moleculen (chemicaliën, fuels)

1. Energie (warmte en elektriciteit)

0 . Verbranden zonder energiebenutting

Het onderbrengen van toepassingen van vezels in de vijf trappen kan ingewikkeld zijn. Met name voor toepassing voor de bodem is het ingewikkeld om te beoordelen welke functionaliteit van toepassing is. Compost en mulch vallen in principe onder vezeltoepassingen, net als stalstrooisel, omdat het vochten nutriënt-houdend vermogen van de vezel hier de functionaliteit is die benut wordt. Eenzelfde redenering geldt voor het inzetten van 'vervezeld' hout in potgrond. De efficiëntie hiervan is echter moeilijk vast te stellen.

De tweede indicator is de benuttingsefficiëntie van de toepassing: dit geeft aan in hoeverre het hout efficiënt is benut. Dus het percentage product ten opzichte van de input of bij energie (1) nuttig ingezette energie ten opzichte van de energie-inhoud van het gebruikte hout.

Als hout voor meerdere toepassingen gebruikt wordt, kan ook een samengestelde indicator berekend worden. Zie de voorbeelden in tabel 6. 
Tabel 6 Voorbeeld van een berekening van een samengestelde indicator voor de hoogwaardigheid voor twee toepassingen van hout uit landschap.

\begin{tabular}{|c|c|c|c|c|}
\hline Toepassing & $\begin{array}{l}\text { Functionaliteit } \\
(0 \text { tot } 4)\end{array}$ & $\begin{array}{l}\text { Materiaal- } \\
\text { efficiëntie }\end{array}$ & $\begin{array}{l}\text { Energie- } \\
\text { efficiëntie }\end{array}$ & Score $^{1}$ \\
\hline Meubels uit rondhout (50\%) & 4 & $50 \%$ & n.v.t. & \\
\hline Papierpulp uit hout (70\%) & 3 & $70 \%$ & & \\
\hline Hout verbrandt in industriële kachel met $80 \%$-efficiëntie & 1 & $100 \%$ & $80 \%$ & 0,8 \\
\hline
\end{tabular}

1 De score wordt berekend door de functionaliteit te vermenigvuldigen met de materiaalefficiëntie (en indien van toepassing vervolgens met de energie-efficiëntie) en dit getal op te tellen voor het totaal van de toepassingen.

Een derde indicator is de herbruikbaarheid: op welk niveau is het product weer te hergebruiken? Hierbij wordt dezelfde schaal gebruikt als bij functionaliteit.

Daarnaast is het belangrijk ook de al bekende indicatoren mee te nemen, zoals broeikasgasbesparing, uitstoot naar de omgeving en economische indicatoren.

$\mathrm{Bij}$ de beoordeling van een toepassing van biomassa moeten behalve functionaliteit of hoogwaardigheid ook andere factoren meegewogen worden. In bijlage 1 is als gedachte-experiment een voorbeeld uitgewerkt.

\subsubsection{Toepassingen van hout uit landschap}

Redenerend vanuit de classificatie van toepassingen zoals in 3.1.2 beschreven, is er een lijst te maken van mogelijke toepassingen van meer hoogwaardig naar laagwaardig:

\section{Houttoepassing}

In Nederland zijn er 86 houtzagerijen die vaak in bepaalde producten en/of boomsoorten zijn gespecialiseerd (Voncken en Oldenburger, 2017). Hieronder vallen de traditionele toepassingen van hout, zoals hout voor planken, meubels, pallets, bouwmaterialen en specifieke producten zoals klompen. Het grootste deel van het stamhout komt uit Nederlandse bossen of wordt geïmporteerd. Stamhout uit landschap speelt maar een zeer beperkte rol en wordt in het onderzoek van Voncken en Oldenburger (2017) niet apart onderscheiden.

Uit de input van experts tijdens de workshop en interviews blijkt dat stamhout uit landschap incidenteel voor houttoepassingen wordt afgezet. Opgemerkt wordt dat in sommige gevallen al het geoogste hout uit landschap wordt gechipt en dus ook het stamhout. Kleine hoeveelheden hout, zoals bij landschapsonderhoud vrijkomen, kunnen in de huidige praktijk niet eenvoudig voor hoogwaardigere toepassingen worden ingezet, omdat volumes van hout bij oogst laag zijn. Voorts speelt mee dat stammen in landschappelijke beplantingen vaak minder recht zijn dan in bossen en daarmee minder geschikt als zaaghout. Een conclusie kan zijn dat hout uit landschap deels wel wordt afgezet voor houttoepassingen, maar dat ook een substantieel deel dat wel voor houttoepassingen geschikt is, als energiehout wordt afgezet (zie onder 1. Energietoepassingen in deze paragraaf), vaak op kleine schaal. Terwijl het in principe af te zetten zou kunnen zijn voor (traditionele) houttoepassingen. 

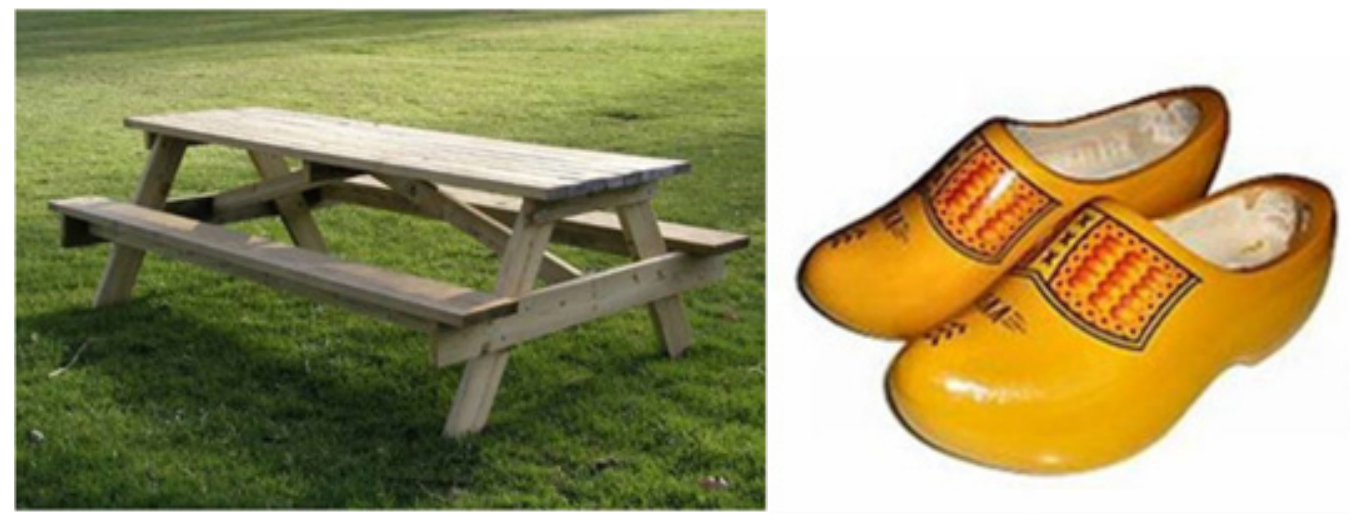

Figuur 6 Een picknicktafel en klompen kunnen van hout uit landschap worden gemaakt.

3. Vezeltoepassing (Papier/pulp, stalstrooisel)

Bij vezeltoepassingen gaat het om het benutten van verkleind hout. Er gaat dus wat functionaliteit verloren ten opzichte van toepassingen onder 4.

Hier gaat het om pulpproductie en ook chips voor toepassing als stalstrooisel. Verder valt hier ook het maken van houtchips onder die afgezet kunnen worden voor het maken van plaatmateriaal. In Gent (BE) staat een fabriek die uit houtchips plaatmateriaal maakt. In Nederland bestaat hiervoor geen industrie. Zoals in tabel 1 (hoofdstuk 2) beschreven, is de afzet voor plaatmateriaal van hout uit landschap marginaal.

\section{Pulp}

Hout kan worden afgezet voor productie van pulp. Hierbij wordt eerst de bast verwijderd. Daarna kan het chemisch of mechanisch worden gepulpt. Bij mechanisch pulpen is de opbrengst tot $90 \%$ (ton pulp/ton houtgrondstof d.s.). De mechanische pulpvezels bestaan uit cellulose, lignine en ook wat hemicellulose. Deze pulp is o.a. geschikt voor kranten en karton.

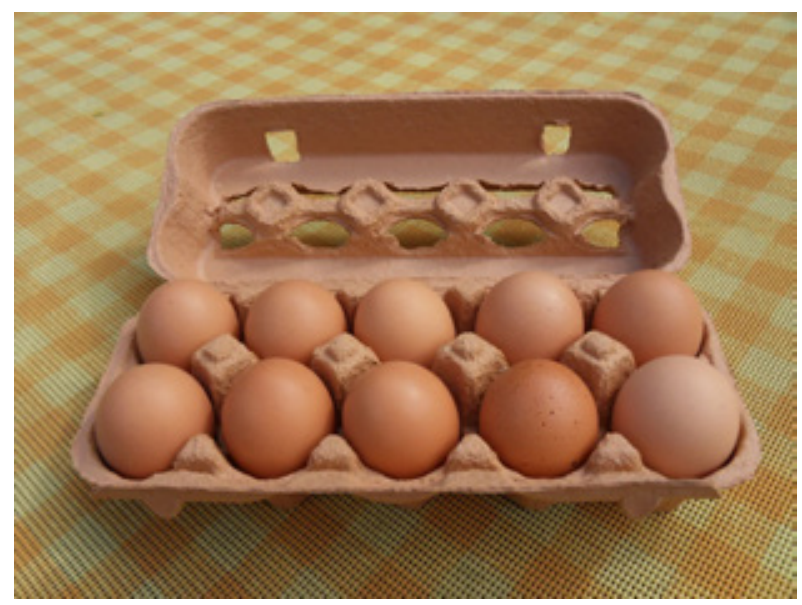

Figuur $7 \quad$ Krantenpapier en karton worden uit pulp gemaakt.

In Nederland is de grondstof hiervoor echter bijna uitsluitend gerecycled papier. In Nederland wordt er alleen op kleine schaal bij de fabriek van Mayr Melnhof in Eerbeek mechanisch gepulpt. Hierbij is de grondstof chip van populierenhout (pers. com. Michiel Adriaanse van KCPK). Hout uit landschap is in principe te benutten voor mechanisch pulpen, maar fabrieken stellen wel specifieke eisen

(bijvoorbeeld uniformiteit, stamhout van één soort, leveringszekerheid etc.), waaraan hout uit landschap in de huidige situatie moeilijk kan voldoen. Er kan ook chemisch worden gepulpt voor de productie van cellulosevezel. Het residu bestaat dan uit 'black liquor', die lignine bevat die nu meestal voor energie wordt ingezet. De lignine kan echter ook in allerlei producten worden toegepast, zoals voor bitumenvervanging in asfalt. Hiermee wordt op dit moment volop geëxperimenteerd. Deze 
toepassing valt in principe in categorie 2 (monomere toepassingen), hoewel de hergebruikstoepassing materiaal is.

Chemische pulp heeft een hogere waarde dan mechanische pulp en wordt voor grafisch papier gebruikt. Alleen wit gerecycled papier is hier in te zetten. Er wordt voor de productie van grafisch papier in Nederland voor een deel wel virgin pulp geïmporteerd. Verder wordt er in Nederland op kleine schaal (orde van grootte 1000 ton/jaar) chemisch gepulpt (dit is nog gedeeltelijk in ontwikkeling) door Van Houtum (nu WEPA) in Swalmen. De grondstof is Miscanthus (een meerjarig gras) dat in Nederland wordt geteeld en waarvoor een langjarige afzet en aanvoer is overeengekomen. In de praktijk is het moeilijk om hout uit landschap aan de specifieke eisen te laten voldoen, zoals aanvoerzekerheid en vooral uniformiteit. Hout uit bossen zal eerder aan deze eisen kunnen voldoen. In het volgende hoofdstuk worden aanbevelingen gedaan over de mogelijkheden deze richting op te gaan.

Chemische pulp (cellulose) is ook de grondstof voor de productie van textielvezels. Hierbij wordt cellulose uit hout of katoen behandeld met natriumhydroxide en dan vermengd met koolstofdisulfide. Hierbij wordt cellulosexanthaat gevormd dat wordt opgelost in meer natriumhydroxide. Dit vormt de viscoseoplossing. Van deze viscoseoplossing kan cellofaan worden gemaakt of het kan worden gesponnen tot rayongaren/kunstzijde. De technologie werd o.a. door de voormalige ENKA-fabriek in Ede gebruikt. In Europa staat er o.a. een moderne fabriek in Oostenrijk van Lenzing, die een aangepast en milieuvriendelijker proces gebruikt. Deze fabriek gebruikt als grondstof beukenhouten chips. Andere veelgebruikte grondstoffen zijn katoen, bamboe en eucalyptus. Blijkbaar eist de fabriek grondstoffen die uniform en schoon zijn en een hoog cellulosegehalte hebben.

Bij de workshop werd naar voren gebracht (bevestigd door pers. comm. Michiel Adriaanse) dat het onwaarschijnlijk is dat er in Nederland in de nabije toekomst echte pulpcapaciteit wordt geïnstalleerd voor papier en karton, omdat er veel aanvoer is van gerecycled papier en inkoop van pulp (uit het buitenland) goedkoper is en aanvoer van uniforme houtchips (uit Nederland) blijkbaar commercieel niet aantrekkelijk is.

Een andere vezeltoepassing is de productie van nano-cellulose. Hierbij wordt houtvezel nog verder verkleind dan bij pulpen. Dit resulteert in zeer kleine deeltjes die veel verschillende toepassingen hebben in verven, papier, eten etc. De geproduceerde hoeveelheden zijn klein, honderden tonnen per jaar wereldwijd (www.tappinano.org). De waarde is zeer hoog ten opzichte van de kosten voor de grondstof. Afzet van hout uit landschap is hiervoor niet een voor de hand liggende optie, omdat men een uniforme en gegarandeerde aanvoer van de grondstof zal willen hebben - wat makkelijker uit bossen of import georganiseerd kan worden.

\section{Monomere toepassingen}

In deze categorie toepassingen wordt hout/vezel verder afgebroken tot moleculen, zoals lignine en suikers zoals glucose en xylose of char en pyrolyseolie.

Lignine kan dan weer voor allerlei producten worden gebruikt, zoals bitumen, maar ook voor smaakstoffen (namaakvanille), jetfuel en scheepsbrandstof.

De suikers kunnen worden gebruikt voor productie van bijvoorbeeld ethanol die als brandstof kan worden gebruikt ( $2^{\mathrm{e}}$ generatie biobrandstof). Wereldwijd zijn er tientallen initiatieven in verschillende stadia van ontwikkeling.

Het is ook mogelijk om de suikers te gebruiken voor de productie van chemicaliën. Zo heeft het Nederlandse bedrijf Avantium een proces ontwikkeld om uit houtchips de suikers vrij te maken (het Zambezi-proces), waarna de suikers worden gebruikt als bouwstenen voor allerlei producten (plastics) en de lignine voor energie wordt gebruikt.

Het is ook mogelijk om hout thermisch af te breken onder zuurstofloze condities, zoals bij pyrolyse of vergassing. Hierbij wordt een mix van moleculen gevormd. Deze kunnen worden verbrand voor energieproductie of kunnen worden gesynthetiseerd tot brandstoffen of chemicaliën. Over het 
algemeen wordt ervan uitgegaan dat vergassing van biomassa tot biobrandstoffen een omvang van meerdere honderdduizend tonnen per jaar per fabriek vergt.

BTG-BTL heeft een commercieel pyrolyseproces ontwikkeld. Hierbij worden uit hout een char (kool), pyrolyseolie en gas geproduceerd. Er staat in Hengelo een eerste full-scale fabriek. Het geproduceerde gas en de char worden momenteel gebruikt voor energieproductie en de pyrolyseolie wordt afgezet voor vervanging van aardgas in een fabriek. Pyrolyseolie kan ook worden gebruikt voor specifieke chemische toepassingen, zoals houtverduurzaming (pers. comm. Richard Gosselink).

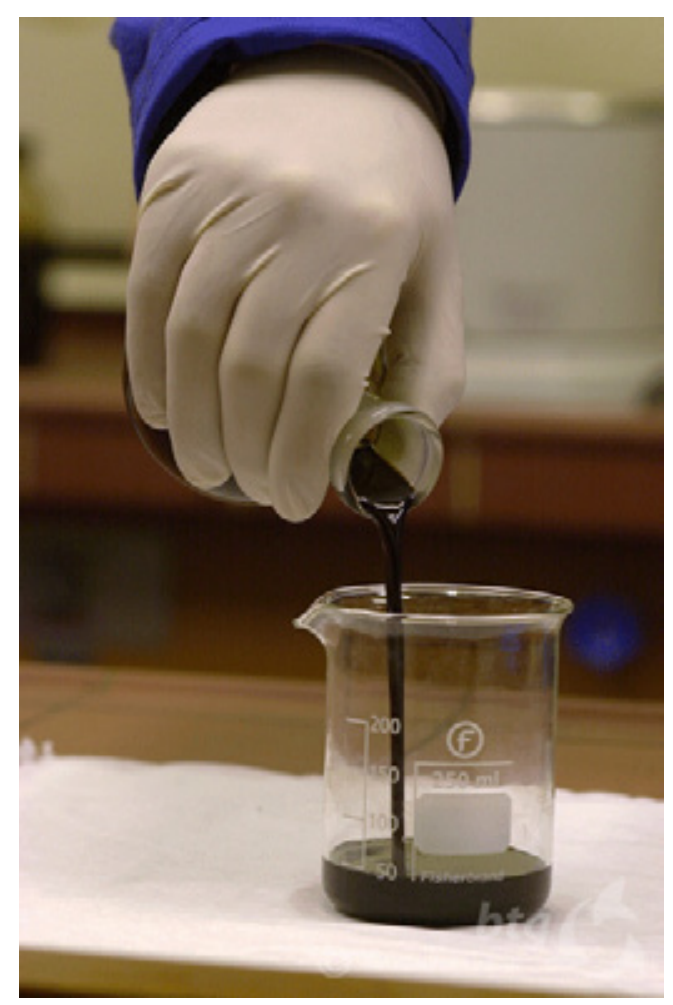

Figuur 8 De productie van pyrolyse-olie uit hout is een commercieel proces geworden.

Pyrolyseolie wordt in Zweden inmiddels gebruikt als grondstof in (olie)raffinaderijen (pers. comm. Gerhard Muggen). De pyrolyseolie wordt dan mee-geraffineerd in raffinaderijen en opgewerkt naar transportbrandstoffen, jetfuel, scheepsbrandstof en chemicaliën. Nu wordt schoon zaagsel als grondstof gebruikt. Gerhard Muggen geeft aan dat het in principe ook mogelijk is om tak- en tophout (uit het landschap) voor pyrolyse te gebruiken. Dan zou het wel uniform moeten worden verkleind en schoon moeten worden gemaakt om o.a. $\mathrm{N}$ en vooral $\mathrm{K}$ te verwijderen. Kalium vermindert de pyrolyseolieopbrengst en kan ook problemen geven bij verbranding.

\section{Energietoepassingen}

Hout en houtachtige biomassa uit het landschap worden momenteel het meest gebruikt voor energietoepassingen (elektriciteit en warmte), zie hoofdstuk 2. Hout wordt in open haarden en kachels thuis gebruikt of wordt eerst gechipt of gepelletiseerd voor verbranding in industriële ovens. De toepassingen voor energieverbruik kunnen worden onderverdeeld in hoofdcategorieën als residentieel gebruik, industriële elektriciteitscentrales voor elektriciteit (inclusief industriële warmtekrachtkoppeling) en industriële ketels voor warmte (zoals stadsverwarming).

In tabel 3 zijn de gegevens van kachels tot 5 MW opgenomen (Koppejan en De Bree, 2018). ${ }^{19}$ De gegevens laten zien dat de efficiëntie van de biomassa benutting sterk verschilt, evenals de uitstoot per eenheid benutte energie.

\footnotetext{
19 J. Koppejan en F. de Bree. 2018. Kennisdocument Houtstook in Nederland. Rapport voor RVO. Procede Biomass BV. Enschede september 2018.
} 
Tabel 3 Overzicht van de opwekking van warmte en de uitstoot uit houtstook tot 5 MW (2018). Ter vergelijking zijn de nationale uitstoot- en de NEC-plafonds weergegeven (overgenomen uit Koppejan en De Bree, 2018).

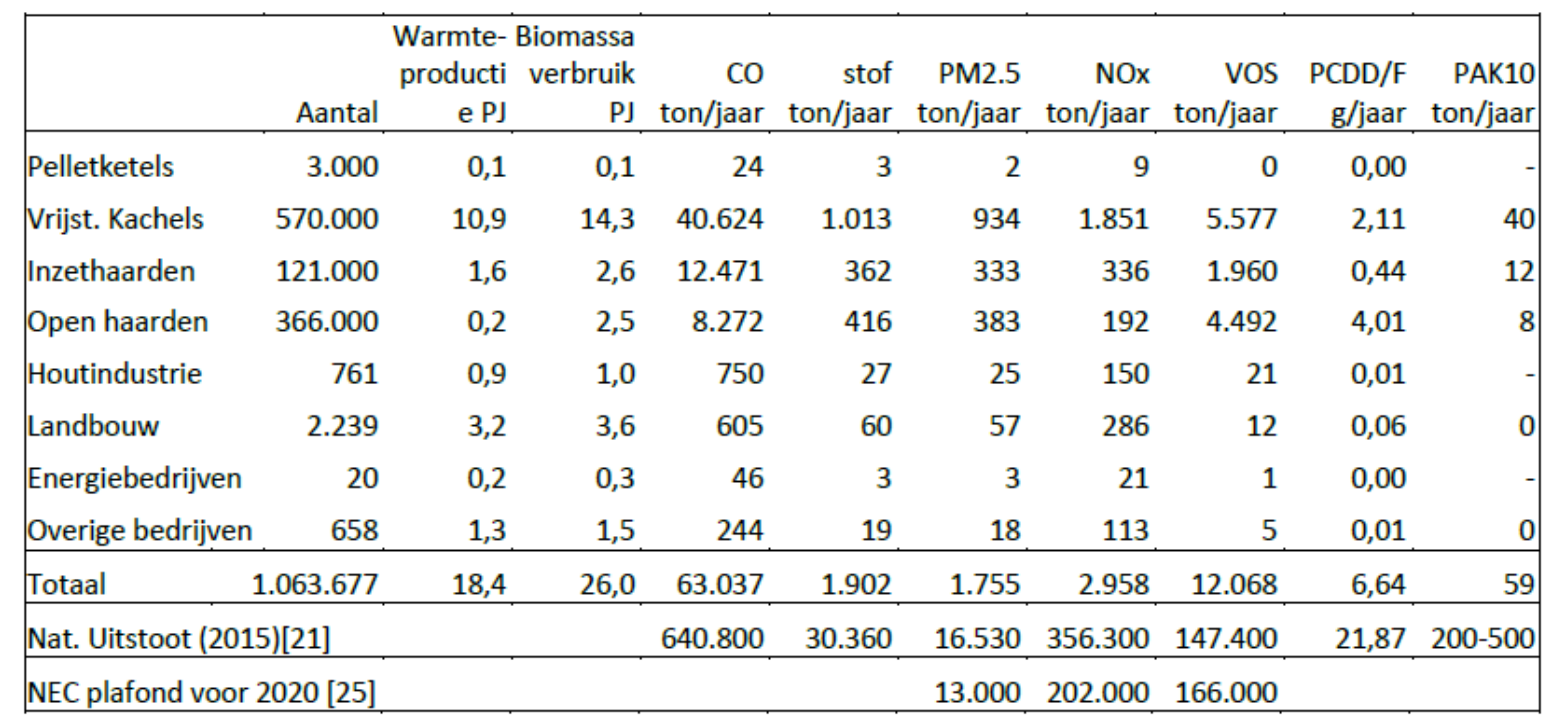

Ongeveer een miljoen huishoudens hebben een houtgestookte installatie. Er zijn drie soorten:

- open haarden

- inzethaarden

- vrijstaande kachels

Open haarden hebben een lage thermische efficiëntie van ongeveer $10 \%$. Inzethaarden en vrijstaande kachels hebben een hoger rendement (aanname $58 \%$ en $75 \%$ respectievelijk). Er is een sterke toename van het aantal vrijstaande kachels (ongeveer $550.000 \mathrm{nu}$ ) ${ }^{20}$.

\section{Industriële energiecentrales}

In biomassagestookte energiecentrales wordt biomassa verbrand voor de productie van hogedrukstoom voor het genereren van elektriciteit. Het netto elektriciteitsrendement bedraagt ongeveer $25 \%$ elektrisch. De restwarmte wordt in veel gevallen voor lokale warmtetoepassingen gebruikt. Bij gecombineerde elektriciteit en warmteproductie (warmtekrachtkoppeling in het Nederlands en CHP, Combined Heat and Power in het Engels) ligt de totale energie-efficiëntie hoger dan enkelvoudige warmte of elektriciteitsproductie. Er zijn ongeveer twintig van die installaties in Nederland.

Bedrijven met grote installaties ( 5 megawatt en meer) produceren vaak overwegend elektriciteit (w/kverhouding van ongeveer 0,5 ). Bedrijven met installaties met een elektrisch vermogen tot 5 megawatt produceren vooral warmte. De warmte/krachtverhouding is daar gemiddeld groter dan $3 .{ }^{20}$

Daarnaast vindt er ook coverbranding plaats van kolen met houtige biomassa. Bij een aantal van deze installaties wordt ook restwarmte benut voor wijkverwarming. Bij coverbranding gaat het meestal om biomassapellets die geïmporteerd worden.

\section{Industriële ketels}

Biomassaketels kunnen worden gebruikt om alleen warmte of stoom te leveren voor gebruik in de industrie en/of in stadsverwarmingssystemen. Hierbij gaat het inmiddels om circa 3600 houtketels met een grootte variërend van $20 \mathrm{~kW}$ tot $10 \mathrm{MW}$. Het gemiddelde thermische rendement is $87 \% .^{20} \mathrm{De}$ meeste houtketels staan in Gelderland, Noord-Brabant en Overijssel. Dit zijn grote provincies met intensieve veehouderij en hout- en meubelindustrie, de sectoren waar de meeste houtketels in gebruik zijn. Noord-Holland staat ook hoog in de lijst wegens de grote installatie voor de stadverwarming in Purmerend. ${ }^{20}$ In Ede levert Warmtebedrijf Ede warmte aan 20.000 woningen via een warmtenet met drie installaties waarin lokaal snoeihout en dergelijke wordt verbrand. Elke centrale verwerkt 30 tot 90 ton snoeihout per dag en kan 9 MW aan warmte produceren (Groenestijn et al., 2019). Zoals hierboven vermeld, zijn installaties die gecombineerd elektriciteit en warmte leveren over het algemeen efficiënter.

${ }^{20}$ CBS 2018. Hernieuwbare energie in Nederland 2017. 


\section{$4 \quad$ Handelingsperspectief}

\subsection{Discussie}

Zoals in hoofdstuk 2 en 3 besproken is, bestaat hout uit landschap voor een groot deel uit tak- en tophout dat een slechtere kwaliteit heeft voor energietoepassingen, maar ook minder vezeltoepassingen mogelijk maakt. Ook het stamhout is - vaker dan in bossen - niet geschikt voor zaaghout in verband met grilliger vormen. Het grootste deel van hout uit landschap wordt nu voor de productie van energie ingezet en/of wordt geëxporteerd (met name ook voor energieproductie).

Er bestaan in principe veel mogelijkheden om hout hoogwaardiger/functioneler in te zetten dan nu gebeurt. In principe zijn er eindeloos veel opties zijn om hout hoogwaardiger te gebruiken.

In de praktijk zijn er echter grote obstakels. De houtige biomassa uit landschap bestaat vooral uit taken tophout en bevat daarmee veel meer nutriënten dan schoon stamhout. Verder komt het hout erg verspreid en in kleine hoeveelheden vrij. De beheerder van het landschap stuurt bij oogstbesluiten niet en zeker niet in de eerste plaats op kwaliteit van hout of de afzet ervan. Veel landschapselementen kennen een lage onderhoudsfrequentie waarbij onderhoud gestuurd wordt door de wens kosten te besparen en het vermijden van schade/risico door vallende bomen en takken.

Er zijn op zich redelijk wat mogelijkheden om stamhout bij zagerijen af te zetten, indien en voor zover het stamhout voldoende recht is en deze stammen bij een hiertoe geëigende zagerij kunnen worden aangeleverd. Momenteel wordt echter ook stamhout uit landschap dat hiervoor geschikt is om praktische of logistieke redenen gechipt en afgezet voor energieproductie.

Voor andere hoogwaardigere toepassingen zoals plaatmateriaal, pulp, pyrolyseolie en brandstoffen en chemicaliën op basis van hout of vezels, ook wel $2^{\mathrm{e}}$ generatie biochemicaliën genoemd, zijn er in Nederland bijna (nog) geen mogelijkheden op dit moment. Deze toepassingen zijn vaak wel in het buitenland te vinden. In Nederland ontbreekt bijvoorbeeld infrastructuur om pulp te produceren. Mocht de vraag naar hoogwaardigere toepassingen in Nederland alsnog ontstaan, dan mag verwacht worden dat deze afnemers hout uit Nederlandse bossen en import eerder op het netvlies hebben dan hout uit landschap.

Want de nieuwe hoogwaardige toepassingen (zoals pyrolyse-olie of hout voor $2^{\mathrm{e}}$ generatie chemicaliën en fuels) stellen hoge kwaliteitseisen aan hout, zoals lage nutriëntgehalten, uniformiteit en leveringszekerheid. Voorts eisen ze ook grotere volumes. Tak- en tophout uit landschap kan hieraan niet direct voldoen. Het zou goed zijn als deze nieuwe hoogwaardigere (dan energie) toepassingen zich zouden richten op stamhout dat niet geschikt is voor zagerijen en op tak- en tophout dat wellicht hiervoor eerst voorbehandeld zou moeten worden. Met betrekking tot het vaak niet-rechte stamhout uit het landschap zou hier een kans kunnen liggen.

Fabrieken die hout (chips of pellets) in (nieuwe) hoogwaardige toepassingen zoals transportbrandstof (jetfuel etc.) of chemicaliën kunnen omzetten (toepassingen die in ons systeem hoogwaardiger zijn dan warmte en elektriciteitsproductie) zijn er (nog) niet. Hoewel er al wel eerste versies (Pyrolyse van BTG/BTL) staan of initiatieven serieus worden ontwikkeld. 


\subsection{Acties richting hoogwaardiger inzet}

In deze paragraaf wordt het handelingsperspectief geschetst. Hierbij worden de verschillende actiepunten langsgelopen van upstream (de plaats waar het landschapshout groeit) tot downstream (de verwerking tot eindproducten).

\section{Richt het landschap zo in dat oogst van het hout met een hogere kwaliteit voor onder meer constructiehout en vezeltoepassingen mogelijk wordt}

Dit is een actie die vooral beheerders van landschap aangaat. Dit is een zeer diverse groep van particuliere landgoederen: van agrariërs, terreinbeherende natuurbeschermingsorganisaties tot gemeenten, waterschappen, provincies en Rijkswaterstaat. Deze actie kent drie verschillende stappen:
a. Beleid
b. Inrichting
c. Beheer

\section{1.a Beleid}

Net als veel bosbeheerders kunnen landschapsbeheerders overwegen de functie (hout)productie vast te leggen in hun beleids- en beheerplannen voor die delen van de landschappelijke beplanting waarvoor dit relevant is. Daardoor is er ook zekerheid dat het hout een product is. In het bosbeheer in Nederland heet dit beleidsmatig 'multifunctioneel bos', in tegenstelling tot bijvoorbeeld 'natuurbos', waarin alleen oogstwerkzaamheden worden uitgevoerd als dit vanuit de natuurfunctie nodig is. Ook bij de aanleg van nieuwe houtige landschapselementen is dit beleid relevant.

\section{1.b Inrichting}

Door het landschap zo in te richten dat het geproduceerde hout makkelijker te oogsten is en van een redelijke kwaliteit en voldoende volume produceert, kan het hout ook makkelijker hoogwaardig worden afgezet. Bij de nieuwe aanleg van landschapselementen is dit relatief gemakkelijker te realiseren. Ook bij de aanleg van bijvoorbeeld nieuwe (fiets)paden kunnen deze zo langs bestaande landschappelijke beplantingen worden geleid dat ze de logistiek van oogst en transport vergemakkelijken. Verder kan er bij de keuze van boom- en struiksoorten ook rekening gehouden worden met gewenste houtsoorten bij de oogst.

\section{1.c Beheer}

Bij beheer en onderhoud kunnen maatregelen zo worden uitgevoerd dat de kwaliteit van het groeiende stamhout in de toekomst een rol speelt bij dunningen. Voorts kan het oogstmoment gekozen worden op een moment dat de takken nagenoeg bladvrij zijn (dit gebeurt vaak al). Ook kunnen bij het onderhoud en oogst soms eenvoudig maatregelen worden getroffen om vervuiling van het takhout met gronddeeltjes te voorkomen.

\section{Stimuleer dat het vrijkomende hout uit landschap zo hoogwaardig mogelijk wordt ingezet} Dit is een actie die vooral de landschapsbeheerder en de eventueel ingezette aannemer, loonwerker en agrarische natuurvereniging aangaat, maar waar ook de mogelijke afnemers bij betrokken moeten worden.

Maak afspraken met partijen die de uitvoering voor hun rekening nemen over de hoogwaardige inzet van de vrijkomende houtige biomassa.

Hiervoor kan bijvoorbeeld in aanbestedingen voor onderhoud van het landschap worden gestuurd en afgerekend op de hoogwaardige inzet van het geproduceerde materiaal (zie actiepunt 3). Vooral grote beheerders kunnen ervoor kiezen zelf de regie en sturing te houden bij de afzet van het geoogste hout en dit niet aan de uitvoerende aannemer over te laten.

Voorts helpt het als de verschillende beheerders van het landschap hierbij samenwerken om duidelijkheid aan de markt te geven (zie ook actiepunt 8), zodat ook de gevraagde volumes beschikbaar zijn en hoogwaardigere toepassingen eerder bediend kunnen worden. 


\section{Ontwikkel een beoordelingssysteem voor hoogwaardigheid en impact van houtige biomassa}

Wij hebben de indruk dat er nu soms wel op broeikaseffect wordt gestuurd bij aanbestedingen, maar niet op de hoogwaardige inzet van het hout.

Een systeem zoals beschreven in paragraaf 3.1.2 zou moeten worden ontwikkeld om onderbouwd afzet richting hoogwaardigheid te sturen - behalve de voorgestelde indicatoren voor 'hoogwaardigheid' (en efficiëntie en herbruikbaarheid), zijn hierbij ook de bestaande impactindicatoren belangrijk (zie bijlage 2).

Advies is om hierbij allereerst te zorgen voor een goede inhoudelijke onderbouwing en bij het opstellen alle spelers in de keten te betrekken, zoals de terreinbeheerders, de aannemers, ngo's, overheden, controleurs, afnemers, bankiers etc. Het is belangrijk dat het een robuust systeem is dat geen misbruik in de hand werkt. Verder is het belangrijk dat er niet meerdere systemen naast elkaar ontstaan waardoor de onduidelijkheid alleen maar toeneemt en de acceptatie afneemt.

\section{Reken aannemers (en andere afnemers van hout) bij inzet van hout voor energietoepassing af op efficiëntie en evt. uitstoot}

Dit actiepunt is een verbijzondering van actiepunt 2 . Dit is als zelfstandig actiepunt opgenomen, omdat, zoals in hoofdstuk 2 beschreven, in de huidige situatie de inzet van hout voor energie het meest voorkomt.

Zoals in hoofdstuk 3 beschreven, zijn er grote verschillen in efficiëntie en impact van energietoepassingen. Met name grotere systemen die efficiënt warmte en elektriciteit maken en die een goede afgasreiniging hebben, zijn te prefereren boven kleinere, inefficiënte systemen die geen afgasreiniging hebben. Dit geldt natuurlijk ook voor de reststromen die vrijkomen bij hoogwaardiger toepassingen van hout (zie hoofdstuk 3).

\section{Classificeer hout uit landschap op verschillende kwaliteiten via fysieke of digitale biomassawerven}

Dit actiepunt is van belang voor de beheerder (de producent van het hout). Maar er ligt ook een belangrijke rol voor de verwerker/tussenhandel/biomassawerf die de 'vertaalslag' maakt tussen de kwaliteiten van het beschikbare hout en de wensen van de verschillende afnemers. Hierbij zou moeten worden gestreefd naar een beperkt aantal uniforme producten volgens nationaal of liever Europees overeengekomen standaarden. De classificatie kan zo ook bijdragen aan de verhandelbaarheid van de diverse deelproducten. Deze classificatie van het hout kan op locatie, maar ook bij biomassawerven gebeuren.

Op dit moment wordt hout uit landschap, zeker als het in kleinere hoeveelheden wordt geoogst, bijna allemaal gechipt en afgevoerd.

Het hoogwaardig benutten van de functionaliteit van hout zou kunnen worden gestimuleerd door het geoogste hout op biomassawerven (ook wel hubs) te verzamelen en daar naar kwaliteit te classificeren. Op deze locatie kan dan hout van uniforme kwaliteit worden aangeboden aan afnemers. Met name voor hoogwaardigere toepassingen zijn de eisen streng en worden ook redelijk grote volumes en leveringszekerheid geëist (zie actiepunt 7).

Voor vrijkomend stamhout van hoge kwaliteit en wellicht voor delen van de vrijkomende houtchips is het wellicht mogelijk de biomassawerf niet op een fysieke locatie, maar als een soort digitale marktplaats in te richten, zodat het transport kan worden geoptimaliseerd (zie actiepunt 7).

Een belangrijke opgave is de opzet en organisatie van de biomassawerven. Ontstaan deze uit doorontwikkeling van bestaande infrastructuur, zoals aanwezig bij composteerbedrijven, houthandel, papierindustrie of gemeentelijke milieustraten en afvalstations of ontstaan er nieuwe regionale coöperaties bestaande uit samenwerkende aanbieders en afnemers van houtige biomassa?

\section{Sorteer voor op hoogwaardigere toepassingen}

Doel is hierbij dat het hout wordt verhandeld in een vorm die nu efficiënt is in te zetten, maar in dezelfde vorm in de nabije toekomst ook hoogwaardiger is in te zetten. Denk hierbij aan uniforme schone houtchips, pellets en pyrolyseolie.

Dit actiepunt geldt voor alle actoren. 
Deze tussenproducten kunnen nu vaak efficiënt (en schoon) worden ingezet voor energietoepassingen, maar ze kunnen op termijn zonder aanpassingen ook voor hoogwaardigere toepassingen worden ingezet (zie verhaal over pyrolyseolie in paragraaf 3.1.3).

Dit betekent ook dat voor landschapsbeheerders en biomassawerven langjarige leveringscontracten (>10 jaar) richting laagwaardige toepassingen kritisch beschouwd moeten worden.

Voor afnemers betekent dit dat investeringen in laagwaardige toepassingen van hout met een afschrijvingsduur van $>10$ jaar kritisch beschouwd moeten worden.

Naar verwachting neemt de productie van hernieuwbare elektriciteit met een lage $\mathrm{CO}_{2}$-uitstoot (vooral wind- en zonne-energie) toe. Zoals ook vermeld in het programma Circulaire Economie van de Rijksoverheid zal de toepassing van biomassa na 2030 moeten verschuiven naar vervangingen van olie (voor transport en chemie) en naar (hout)producten die bijvoorbeeld beton en staal vervangen. Dus het advies is om bij de huidige toepassingen van hout (met name het tak- en tophout en de kromme stammen) uit landschap te sturen richting toepassingen die makkelijk richting hoogwaardigere toepassingen zijn om te buigen. Hierbij gaat het bijvoorbeeld om de productie van pellets en pyrolyseolie. Deze tussenproducten worden nu vrijwel uitsluitend voor energieproductie gebruikt. Maar die producten kunnen in de nabije toekomst gebruikt worden voor productie van transportbrandstoffen en chemicaliën.

\section{Creëer een marktsysteem voor afzet van hout en dus ook hout uit landschap}

Het bij elkaar brengen van producenten en de afnemers van hout is nu nog niet in een (officieel en transparant) marktsysteem geregeld. Een elektronisch handelssysteem waarbij hout of houtige tussenproducten worden verhandeld, kan ervoor zorgen dat vraag en aanbod beter met elkaar in overeenstemming komen. Het Baltpool-systeem (www.baltpool.eu) is hiervan een voorbeeld. De efficiëntie van de markt zou erdoor kunnen toenemen (pers. comm. Biljana Kulišić). Het verdient aanbeveling hiervoor samen te werken met alle aanbieders en afnemers van schoon afvalhout en van biomassastromen afkomstig uit stedelijk groen, landschap en bossen. Biomassawerven kunnen hier ook een rol spelen (zie actiepunt 5).

\section{Samenwerking tussen landschapsbeheerders, biomassawerven en potentiële afnemers} Overleg en samenwerking tussen deze partijen, waaronder ook de uitvoerders van het onderhoud, kunnen helpen bij het zetten van stappen richting hoogwaardigere toepassing van de vrijkomende biomassa. Hier ligt een aantal uitdagingen upstream (zie met name actiepunten 1 tot en met 5), maar het is belangrijk om ook de downstream-kant niet te vergeten. Momenteel is het relatief gemakkelijk bij hoogwaardige toepassingen om strenge eisen te stellen aan de houtige biomassa als inputmateriaal, omdat dit materiaal in Nederland via import relatief gemakkelijk beschikbaar is. Door te innoveren richting productieprocessen die een breder spectrum aan biomassa kunnen verwerken en/of richting voorproductiestappen die door beheerder/biomassawerf of bij de verwerker realiseerbaar zijn, komt hoogwaardige toepassing van houtige biomassa uit landschap dichterbij.

\section{Overheid als launching customer}

De overheid kan nieuwe en bestaande innovaties met landschapshout mogelijk maken of versnellen door deze producten zelf af te nemen. De gezamenlijke overheden zijn een grote marktpartij. Met name nieuwe producten vergen veel investeringen die alleen van de grond komen als er een markt is. De overheid als launching customer kan dan een belangrijke rol spelen om een van de onzekerheden, de afzet, af te dekken. Hierbij zou de overheid eisen kunnen stellen aan het aandeel van de houtige biomassa afkomstig uit Nederlandse beplantingen (in landschap, stad of bos) dat verwerkt is in een bepaald product. 


\section{$5 \quad$ Conclusies}

In Nederland willen we biomassa graag hoogwaardig benutten. Voor dit rapport is er daarom een aanzet voor een classificatiesysteem ontwikkeld om toepassingen van hout van hoog- naar laagwaardig te kunnen indelen, dat gebaseerd is op het benutten en het behouden van de functionaliteit van hout.

Hout uit het landschap wordt nu vooral voor energieproductie (elektriciteit en warmte) ingezet. Dit wordt als een relatief laagwaardige toepassing gezien, hoewel er grote verschillen zijn binnen deze toepassing: van inefficiënt en vies (open haarden) tot relatief schoon en efficiënt (biomassacentrales met warmte- en elektriciteitsproductie WKK).

Er zijn veel obstakels om hout uit landschap hoogwaardiger in te zetten, bijvoorbeeld voor producten of voor het maken van papier en ook voor de productie van chemicaliën, zoals de relatief lage kwaliteit en de geringe uniformiteit van hout uit landschap, de geringe volumes, de versnippering van de afzet over vele soorten ketens en het gebrek aan afzetmogelijkheden in Nederland. Voor afzet naar hoogwaardigere toepassingen moet deze houtstroom voldoen aan andere en vaak hogere eisen.

Er moet duidelijkheid komen over wat er onder hoogwaardigheid wordt verstaan, zodat hier ook op kan worden afgerekend. Het is belangrijk te beseffen dat hierbij ook efficiëntie en andere impactcategorieën als broeikaseffect meegenomen worden. (In bijlage 2 staat een aanzet voor zo'n systeem.)

Een quick-fix om dit hout snel hoogwaardig(er) af te zetten, is niet mogelijk. Het advies is om voor te sorteren op hoogwaardiger inzet van hout uit landschap door tussenproducten te maken die voor energie - nu en de eerstkomende jaren - en later voor hoogwaardigere toepassingen zijn te gebruiken. Een voorbeeld hiervan is de omzetting naar pyrolyseolie of de productie van uniforme pellets.

Hierbij moet worden samengewerkt met andere landschapsbeheerders, houtproducenten en andere spelers in de keten, zoals aannemers. Maar ook met de huidige en toekomstige afnemers en ook met financiers en technologieproducenten. De huidige en toekomstige afnemers moeten deze biomassa kunnen en willen gebruiken. Om het kwaliteitsprobleem op te lossen, moeten er biomassawerven komen waar biomassa wordt geclassificeerd of voorbewerkt tot uniforme tussenproducten. Zo kunnen de kleine volumes landschapshout meeliften met de andere houtstromen. Bij de classificatie moet goed worden samengewerkt met afnemers en producenten van houtige biomassa.

Ook de afnemers van houtige biomassa hebben een uitdaging. Het is mogelijk om hoge eisen aan biomassa te stellen, maar de kans dat er dan geconcurreerd wordt met hoogwaardigere toepassingen van hout is dan groot. Het is belangrijk dat robuuste technologieën ontwikkeld worden die ook geschikt zijn voor verwerking van lagere kwaliteit hout. Dit betekent investeringen in productieprocessen en voorbewerkingsstappen.

De overheid kan - als launching customer - bovenstaande ontwikkelingen versnellen door bij de inkoop van tal van producten slimme eisen te stellen aan de herkomst van de inputmaterialen ervan. 


\section{Literatuur en referenties}

\section{Geraadpleegde literatuur}

Agentschap NL (2011). Torrefactie: biomassa omzetten in groene steenkool. Agentschap NL. oktober 2011. Publicatie-nr. DENB1106.

Baas H, Van Herwaarden GJ (2016). De staat van het landschap. Vakblad Natuur Bos en Landschap november 2016.

Boosten M, Oldenburger J, Kremers J, Van den Briel J, Spliethof N, Borgman D (2018). Beschikbaarheid van Nederlandse verse houtige biomassa in 2030 en 2050: Studie naar binnenlands potentieel en toekomstige vraag vanuit energie en biobased ontwikkelingen. Rapport Stichting Probos, Wageningen, 80p.

Doorn A van, Nieuwenhuizen W, Meijer M, Snepvangers J, Van Herwaarden GJ, Kamerling A (2016). Samen naar een registratie van groene en blauwe landschapselementen: Een haalbaarheidsstudie. Alterra rapport 2733

Edward Thomas \& BuehImann (2017). https://www.fs.fed.us/nrs/pubs/jrnl/2017/nrs_2017_thomas_001.pdf

J. van Groenestijn, P. Harmsen, H. Bos. (2019). Biomassa voor de Circulaire Economie. Groene Grondstoffen.

E. van Groningen, W. van der Knaap, J.H. Spijker, D.J. Stobbelaar 2013, Biomassa uit natuur en landschap. KennisCentrum Agrofood en ondernemen.

Handreiking regionale energiestrategieën (2018). Handreiking voor regio's ten behoeve van het opstellen van een Regionale Energiestrategie. Versie 20 december 2018. Rijksoverheid, InterProvinciaal Overleg, Unie van Waterschappen, Vereniging van Nederlandse Gemeenten.

Koomen AJM, Maas GJ, Weijschede TJ (2007). Veranderingen in lijnvormige cultuurhistorische landschapselementen: Resultaten van een steekproef over de periode 1900-2003. Wageningen, Wettelijke Onderzoekstaken Natuur \& Milieu, Wot-rapport 34.

Koppejan J, Elbersen W, Meeusen M, Bindraban P (2009). Beschikbaarheid van Nederlandse biomassa voor elektriciteit en warmte in 2020. Rapportage in opdracht van SenterNovem, 99p.

Kuiper R (2015). Verkenning Omgevingsopgaven voor de Nationale Omgevingsvisie. Den Haag: Planbureau voor de Leefomgeving

Mantau U, Saal U, Prins K, Steierer F, Lindner M, Verkerk H, Eggers J, Leek N, Oldenburger J, Asikainen A, Anttila P (2010). Real potential for changes in growth and use of EU forests. EUwood. Final report. Hamburg/Germany, 160p.

Ministerie van Economische Zaken (2015). Biomassa 2030; Strategische visie voor de inzet van biomassa op weg naar 2030 https://www.rijksoverheid.nl/documenten/rapporten/2015/12/01/biomassa-2030

Ministerie van Infrastructuur en Milieu en ministerie van Economische Zaken (2016). Nederland circulair in 2050. Rijksbreed programma Circulaire Economie, 72p. 
Nabuurs GJ, Van den Briel (2017). Actieplan Bos en Hout: Een verandering in het denken over de bosen houtketen in Nederland. Vakblad Natuur Bos en Landschap, februari 2017, p3-7.

Oldenburger J, Boosten M (2019). Factsheet resultaten biomassaenquête 2018. Bosberichten

Oldenburger J, De Groot C, Winterink A (2012). Nederlandse houtstromen in beeld. Wageningen, Stichting Probos, 64p.

Planbureau voor de Leefomgeving (2019). Zorg voor landschap. Naar een landschapsinclusief omgevingsbeleid. Den Haag: PBL

Rijksoverheid (2018). https://www.klimaatakkoord.nl/landbouw-enlandgebruik/documenten/publicaties/2019/06/28/klimaatakkoord-hoofdstuk-landbouw-enlandgebruik

Sluijsmans JJL, JH Spijker (2019) Duurzame productie van biomassa voor de productie van waterstof. Een beoordeling vanuit de klimaatopgave. Wageningen Environmental Research, Rapport 2951.

Snepvangers J, Van de Wiel L, Raap E (2013). Resultaten Meetnet Agrarisch Cultuurlandschap.

Vries W de, De Jong A, Kros H, Spijker J (2019). Het effect van houtoogst op nutriëntenbalansen in bossen op zandgronden: Onderbouwing van een adviessysteem. Wageningen Environmental Research rapport 2923.

Voncken, F. en J. Oldenburger (2017). De Nederlandse rondhoutzagerijsector. Een analyse met het oog op de toekomstige rondhoutverwerkingscapaciteit. Probos rapport.

\section{Geraadpleegde websites}

CBS (2019). Aandeel hernieuwbare energie naar 7,4 procent. Geraadpleegd van https://www.cbs.nl/nl-nl/nieuws/2019/22/aandeel-hernieuwbare-energie-naar-7-4-procent

Branche Vereniging Organische Reststoffen (2018). Onbehandeld (vers) resthout: afval of niet? Geraadpleegd van https://bvor.nl/blog/onbehandeld-vers-resthout-afval-of-niet/

Ecovero (z.d.). Eco-responsible production: the next milestone in Lenzing's sustainability journey. Geraadpleegd van https://www.ecovero.com

Latvijas Finieris (2019). New lignin based glue for riga plywood. Geraadpleegd van https://www.finieris.com/en/company/news/news/riga-ecological-\%E2\%80\%93-new-ligninbased-glue-for-riga-plywood

Wageningen University \& Research (2017). Duurzaam bio-asfalt uit lignine. Geraadpleegd van https://www.wur.nl/nl/project/Duurzaam-bio-asfalt-uit-lignine.htm

https://www.lenzing.com/sustainability/production/fiber-production

Sweco (2017). Eerste biocomposieten fietspad van Nederland. Geraadpleegd van https://www.sweco.nl/nieuws/nieuwsartikelen/persbericht-eerste-biocomposieten-fietspad-vannederland/

BKgroen: https://www.bkgroen.nl/

https://www.wepa.nl/

https://www.btg-btl.com/

https://www.baltpool.eu/en/supply-price-by-regions/ 


\section{Interviews}

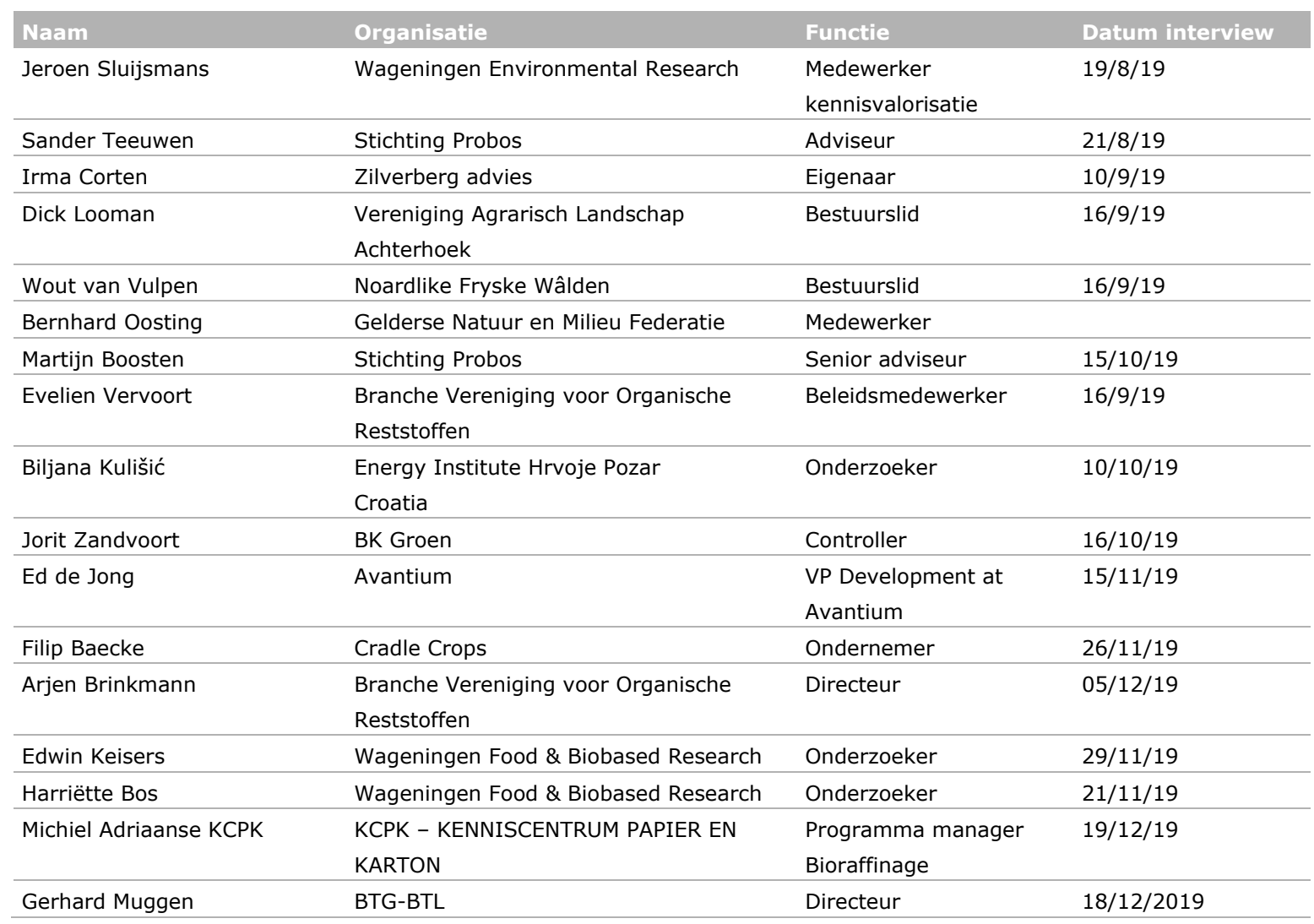




\section{Bijlage 1 Voorbeeld van een uitwerking van de beoordelingsmatrix}

Deze uitwerking is het resultaat van een vingeroefening. Dit is een allereerste aanzet voor actiepunt 3 van het handelingsperspectief (zie hoofdstuk 4).

De verschillende criteria en de inschaling moeten nog verder worden uitgewerkt. Voor deze tabel zijn onderstaande, voorlopige uitgangspunten gehanteerd:

\section{Toegevoegde waarde}

Opbrengsten van het hout excl. subsidie minus productiekosten. Indicatief:

4: $>400 € /$ ton d.s.

3: $250-400 € /$ ton d.s.

2: $100-250 € /$ ton d.s.

1: $0-100 € /$ ton d.s.

0 : geen waarde

\section{Broeikasgassen}

Inschalen op basis van vasthouden van in hout opgeslagen koolstof en vermijden van broeikasgasemissies.

\section{Bodemkwaliteit}

Toevoegen nutriënten, organische stof of verbeteren bodemstructuur. Bijv. bij ter plekke achterlaten of terugbrengen van restmateriaal (in buitenland wordt soms bodem-as als meststof teruggebracht na verbranding.

\section{Biodiversiteit}

Bij achterlaten van biomassa kan een positieve bijdrage aan de biodiversiteit ontstaan door het bieden van schuil- en nestgelegenheid. Ook dood hout (staand of liggend) heeft een belangrijke ecologische functie. Dit kan echter prima worden gecombineerd met productiefuncties die kunnen zorgen voor een vitale landschappelijke beplanting.

\section{Luchtkwaliteit}

Hierbij gaat het met name om de uitstoot van schadelijke stoffen, zoals NOx en fijnstof.

\section{Werkgelegenheid}

Hier gaat het om een uitwerking van de hoeveelheid betaalde arbeid per ton droge stof. Kwaliteit van de arbeid en werkgelegenheid voor mensen met een zekere afstand tot de arbeidsmarkt zouden ook kunnen worden meegenomen.

\section{Rurale ontwikkeling}

In dit criterium wordt meegenomen in hoeverre het bijdraagt aan de lokale/regionale economie.

\section{Functionaliteit}

In hoeverre blijft de functionaliteit behouden? Bij achterlaten scoort dit criterium hoger dan verbranden in verband met bijdrage aan organische stof en nutriënten in bodem.

\section{Biomassa-Gebruiksefficiëntie}

Het percentage van de houtige biomassa dat voor de toepassing kan worden ingezet.

\section{Mogelijkheid hergebruik}

Is de houtige biomassa herbruikbaar en zo ja, blijft het functionaliteitsniveau behouden of treedt hier verlies op? 


\section{Technology Readiness Level (TRL)}

In hoeverre is de methode al beschikbaar?

\section{Aanwezigheid infrastructuur}

Is de benodigde infrastructuur beschikbaar?

\section{Stimuleringsbeleid}

Hier gaat het om beschikbare subsidies of andere stimuleringsmaatregelen van de overheid.

\section{Aanwezigheid van andere duurzame alternatieven}

In hoeverre zijn er andere duurzame alternatieven beschikbaar (materiaal kan slechts eenmaal worden ingezet)?

Zie tabel hieronder:

\begin{tabular}{|c|c|c|c|c|c|c|}
\hline \multirow[t]{2}{*}{$\begin{array}{l}\text { Toepassingen } \rightarrow \\
\text { Criteria } \downarrow\end{array}$} & \multirow{2}{*}{$\begin{array}{r}\text { Achterlaten } \\
\text { Base Case }\end{array}$} & $\begin{array}{l}\text { Huishoudelijke } \\
\text { kachels (hout) - } \\
\text { openhaard }\end{array}$ & $\begin{array}{l}\text { Industriële } \\
\text { energie- } \\
\text { centrales } \\
\text { (chips) - CHP }\end{array}$ & \multirow[t]{2}{*}{ Pyrolyse } & $\begin{array}{l}\text { Hout } \\
\text { producten } \\
\text { (lokale } \\
\text { constructie) }\end{array}$ & Pulp/papier \\
\hline & & \multirow{2}{*}{\multicolumn{3}{|c|}{ Energie }} & \multicolumn{2}{|c|}{ Materiaal } \\
\hline Economische criteria & & & & & & \\
\hline Toegevoegde waarde & 0 & 2 & 1 & 1 & 3 & 2 \\
\hline \multicolumn{7}{|l|}{ Milieucriteria } \\
\hline Broeikasgassen & 1 & 0 & 3 & 3 & 4 & 2 \\
\hline Bodemkwaliteit & 2 & 0 & 0 & 0 & 0 & 0 \\
\hline Biodiversiteit & 3 & 0 & 0 & 0 & 0 & 0 \\
\hline Luchtkwaliteit & 4 & 0 & 2 & 2 & 4 & 3 \\
\hline \multicolumn{7}{|l|}{ Sociale criteria } \\
\hline Werkgelegenheid & 0 & 2 & 2 & 2 & 4 & 2 \\
\hline Rurale ontwikkeling & 0 & 3 & 2 & 2 & 4 & 2 \\
\hline $\begin{array}{l}\text { Voorsoorteren op } \\
\text { hoogwaardige } \\
\text { toepassingen }\end{array}$ & 0 & 0 & 1 & 4 & 1 & 1 \\
\hline \multicolumn{7}{|l|}{ Circularity criteria } \\
\hline Functionaliteit & 2 & 1 & 1 & 1 & 4 & 3 \\
\hline $\begin{array}{l}\text { Biomassa } \\
\text { gebruiksefficiëntie }\end{array}$ & 1 & 1 & 4 & 3 & 3 & 3 \\
\hline $\begin{array}{l}\text { Mogelijkheden } \\
\text { hergebruik }\end{array}$ & 0 & 0 & 0 & 0 & 3 & 4 \\
\hline \multicolumn{7}{|l|}{ Uitvoerbaarheid } \\
\hline $\begin{array}{l}\text { Technology readiness } \\
\text { level (TRL) }\end{array}$ & 4 & 4 & 4 & 3 & 4 & 4 \\
\hline $\begin{array}{l}\text { Aanwezigheidf } \\
\text { infrastructuur }\end{array}$ & 4 & 4 & 4 & 3 & 4 & 3 \\
\hline Stimuleringsbeleid & 1 & 0 & 4 & 4 & 1 & 1 \\
\hline $\begin{array}{l}\text { aanwezigheid van } \\
\text { andere duurzame } \\
\text { alternatieven }\end{array}$ & 1 & 1 & 2 & 2 & 3 & 3 \\
\hline $\begin{array}{l}\text { Som gelijke } \\
\text { waardering }\end{array}$ & 23 & 18 & 30 & 30 & 42 & 33 \\
\hline
\end{tabular}




\title{
Bijlage 2 Samenstelling klankbordgroep en deelnemers workshop
}

\author{
Leden Klankbordgroep \\ Paula Huismans \\ RWS WVL (projectcoördinatie) \\ Bas de Leeuw \\ RWS PPO BUNK \\ Catrinus Nouta \\ RWS GPO (projectcoördinatie) \\ Monique Riphagen \\ Ministerie I\&W (opdrachtgever aan Rijkswaterstaat) \\ Wieger Dijkstra \\ Ministerie I\&W (opdrachtgever aan Rijkswaterstaat) \\ Remco Gras \\ RVO \\ Peter de Jong \\ Stichting Natuur \& Milieu \\ Petra Bakker \\ RWS WVL (agendalid) \\ Ida Smit \\ RVO (agendalid)
}

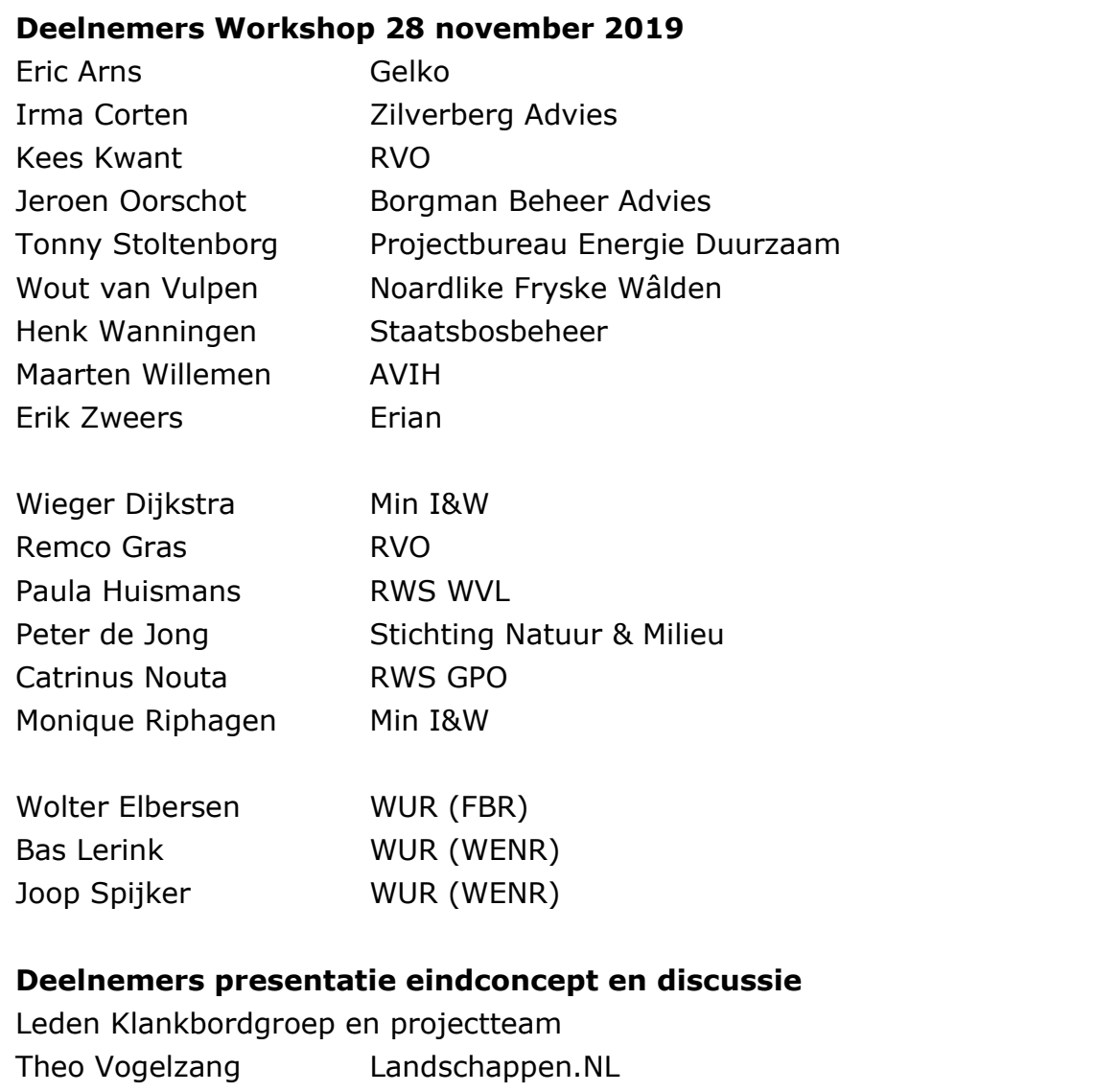


Wageningen Environmental Research Postbus 47

6700 AA Wageningen

T 0317480700

www.wur.nl/environmental-research

Wageningen Environmental Research Rapport 2991

ISSN 1566-7197
De missie van Wageningen University \& Research is 'To explore the potential of nature to improve the quality of life'. Binnen Wageningen University \& Research bundelen Wageningen University en gespecialiseerde onderzoeksinstituten van Stichting Wageningen Research hun krachten om bij te dragen aan de oplossing van belangrijke vragen in het domein van gezonde voeding en leefomgeving. Met ongeveer 30 vestigingen, 5.000 medewerkers en 12.000 studenten behoort Wageningen University \& Research wereldwijd tot de aansprekende kennisinstellingen binnen haar domein. De integrale benadering van de vraagstukken en de samenwerking tussen verschillende disciplines vormen het hart van de unieke Wageningen aanpak. 



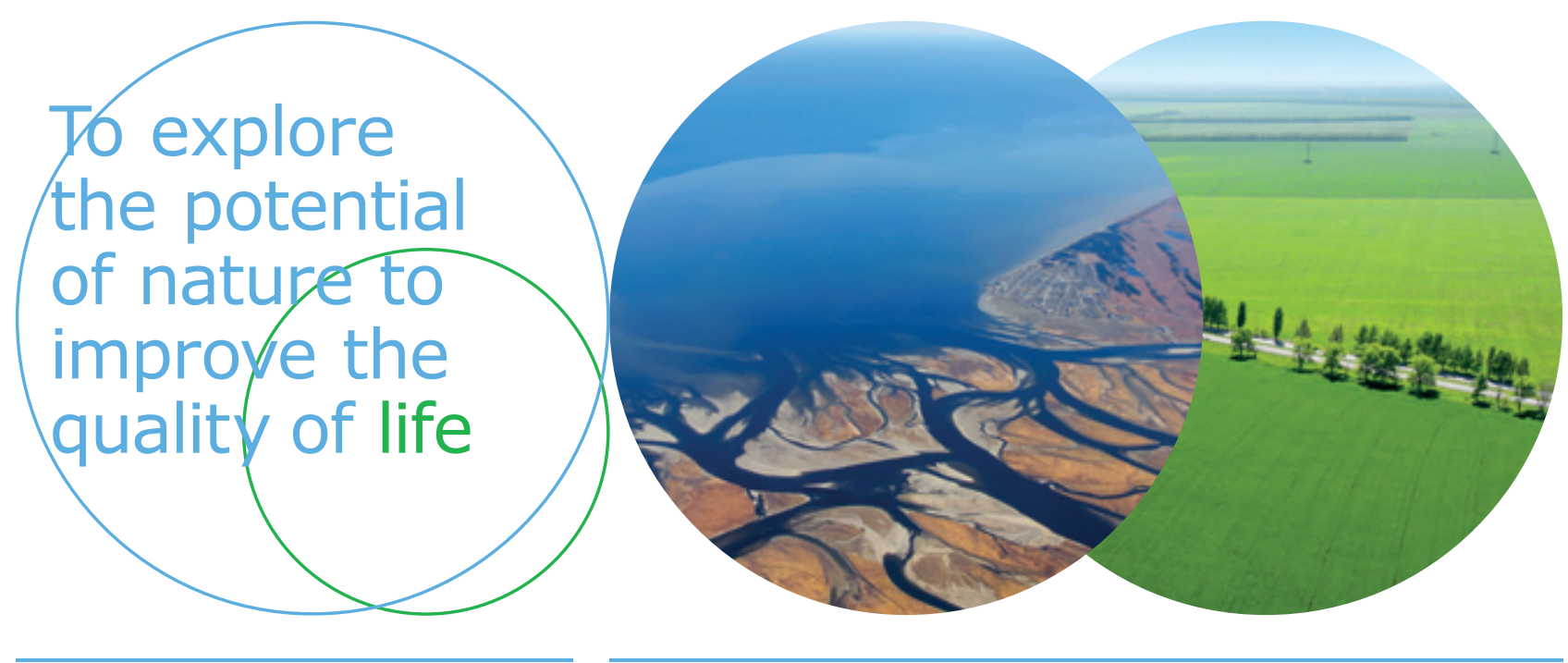

Wageningen Environmental Research Postbus 47

$6700 \mathrm{AB}$ Wageningen

T 317480700

www.wur.nl/environmental-research

Rapport 2991

ISSN 1566-7197
De missie van Wageningen University \& Research is 'To explore the potential of nature to improve the quality of life'. Binnen Wageningen University \& Research bundelen Wageningen University en gespecialiseerde onderzoeksinstituten van Stichting Wageningen Research hun krachten om bij te dragen aan de oplossing van belangrijke vragen in het domein van gezonde voeding en leefomgeving. Met ongeveer 30 vestigingen, 5.000 medewerkers en 12.000 studenten behoort Wageningen University \& Research wereldwijd tot de aansprekende kennisinstellingen binnen haar domein. De integrale benadering van de vraagstukken en de samenwerking tussen verschillende disciplines vormen het hart van de unieke Wageningen aanpak. 